\title{
Bulanık Mantık: 2000-2020 Yılları Arası Tez ve Makale Çalışmalarına Yönelik Bir İçerik Analizi
}

\section{Fuzzy Logic: A Content Analysis For Thesis And Article Studies Between 2000-2020}

\author{
Oğuzhan Özdemir ${ }^{1}$ (D), Yusuf Kalınkara² ${ }^{2}$ (])
}

${ }^{1}$ Doç. Dr., Frrat Üniversitesi, Eğitim Fakültesi, Bilgisayar ve Öğretim Teknolojileri Eğitimi Bölümü, Elazığ, Türkiye

${ }^{2}$ Doktora Öğrencisi, Frrat Üniversitesi, Eğitim Bilimleri Enstitüsü, Bilgisayar ve Öğretim Teknolojileri Eğitimi Bölümü, Elazığ, Türkiye

ORCID: O.Ö. 0000-0002-5310-6605; Y.K. 0000-0001-6077-9800

\section{Corresponding author:}

Yusuf KALINKARA

Fırat Üniversitesi, Eğitim Bilimleri Enstitüsü, Bilgisayar ve Öğretim Teknolojileri Eğitimi Bölümü, Elazığ, Türkiye

E-mail address: yusufkalinkara@gmail.com

Submitted: 02.07.2020

Revision Requested: 12.11 .2020

Last Revision Received: 14.11.2020

Accepted: 14.11.2020

Citation: Özdemir, O., ve Kalınkara, Y. (2020). Bulanık mantık: 2000-2020 yılları arası tez ve makale çalışmalarına yönelik bir içerik analizi.

Acta Infologica, 4(2), 155-174.

https://doi.org/10.26650/acin.762872

\section{ÖZ}

Günümüzde performans belirleme çalışmalarının yanı sıra karar verme süreçlerinde de niceliksel veriler kullanılmaktadır. Nicel verilerin kullanılması, sözel olarak ifade edilebilen bazı durumların matematiksel olarak ifade edilebilmesini engellemektedir. Bulanık mantık bu problemi çözmek için geçerli ve güvenilir bir yol sunmaktadır. Bulanık mantık yaklaşımı, karar alırken kesin olmayan bilgilerin de işin içine katılmasına imkân tanır. Böylelikle bulanık mantık, klasik mantık ile matematiksel olarak ifade edilemeyen bilgilerin formüle edilmesine imkân tanır.

Bu çalışmada bulanık mantık yaklaşımından bahsedilmiş ve bulanık mantığın sunduğu avantajlar, neden olduğu dezavantajlar ortaya konulmuştur. Bulanık mantık günümüzde birçok alanda kullanılmaktadır. Eğitimde de bulanık mantık kullanılmasına dair alan yazında çalışmalara rastlanmaktadır. Bu çalışmalara genel bir bakış sunmak, hangi alanlarda bulanık mantığın tercih edildiğine bakmak önemlidir. Yapılan alan yazın taramasında bulanık mantı̆̆ın eğitim ile ilgili çalışmalarında çoğunlukla performans belirleme, başarı ölçme/karşılaştırma, farklı öğrenme stillerinin etkilerini ölçme, zeki öğrenme ve performans sistemleri tasarlanmasında, alan/meslek seçiminde, oyun tasarımında kullanıldığı görülmüştür.

Anahtar kelimeler: Bulanık Mantık, Eğitim, İçerik Analizi

\section{ABSTRACT}

Today, quantitative data are being used to guide decision making processes as well as in performance determination studies. Using quantitative data prevents situations that can be expressed verbally from being expressed mathematically. Fuzzy logic offers a valid and reliable way to solve this problem. The fuzzy logic approach allows the inclusion of uncertain information while making decisions, thus making it possible to formulate information that cannot be expressed mathematically with classical logic.

In this study, the fuzzy logic approach is described along with its advantages and disadvantages. Fuzzy logic is being used in many fields today. There have been studies on the use of fuzzy logic in education. It is important to provide an overview of these studies and understand which areas of fuzzy logic are preferred. In the literature review, it was seen that fuzzy logic was mostly used in performance determination, measuring/comparing success, measuring the effects of different learning styles, designing intelligent learning and performance systems, field/profession selection, and game design in studies related to education. Keywords: Fuzzy Logic, Education, Content Analysis 


\section{GİRIŞ}

Günümüzde birçok işlemde karar verirken Aristo mantığını tercih ederiz. Mesela yarın hava sıcaklığının durumuna bakarken sıcaklık değerine göre havanın sıcak ya da soğuk olacağı hakkında kesin karar veririz. Aristo mantı̆̆1 olayları, olguları, kararları doğru - yanlış siyah ya da beyaz olarak nitelememize neden olur. Arada kalan belirsiz alanların sınıflandırılmasında Aristo mantığının yeterince hassas davranmadığı düşünülebilir. Bulanık mantık ve bulanık küme teorisi klasik mantık ile yeterince hassas ölçülemediği düşünülen değerlerin daha hassas ölçülmesinde önemli bir rol üstlenmektedir.

Günlük hayatta kullandığımız birçok ifade aslında bulanık bir yapıya sahiptir. Örneğin, insanların yaş durumları ile ilgili yaşlı, orta yaşlı, genç gibi ifadeler bulanık mantığın gündelik yaşamda kullanımına örnektir. İnsan beyni de bu tür belirsiz ifadelere ve belirsiz durumlara alışmıştır. Bu nedenle de bulunduğumuz odanın ışı̆̆ı yetersiz ise 1şığı biraz arttırırız (Altaş, 1999).

Bulanıklılık kavramı esasında dünyamızın sadece sıfır ve birlerden oluşmadığını iddia eder. Sıfır ve bir arasında yüzlerce aralık ve kesiklik bulunmaktadır (Işıkl1, 2008). Bulanık mantık yaklaşımı, dünyamızdaki durum, olgu ve olayların, karar verme mekanizmalarının aslında kesintisiz süreçler olduğunu, siyah-beyaz, doğru-yanlış, başarılı - başarısız şeklinde kesin hatlar ile ayrılamayacağını ifade eder.

Belirsizlik içeren durumların çözümünde Lotfi A. Zadeh tarafından 1965 yılında yayınlanan bulanık mantık teorisi önemli bir yer tutmaktadır. Bu teori zamanla gelişmesi ve daha fazla alanda kullanılmaya başlanması ile önemli hale gelmiştir (Altaş, 1999). Bulanık mantığın babası olarak nitelendirilen Lotfi A. Zadeh, bu alanda bilime birçok kavram ve yasa kazandırmıştır. Bulanık koşullarda karar verebilme, bulanık küme, yaklaşıksal akıl yürütme kuramı, dilbilimsel değişkenler kuramı, bulanık eğer - öyleyse kuramı gibi birçok kuram ve yaklaşımda Lotfi A. Zadeh’in imzası vardır (Işıklı, 2010).

İlk çıktığ1 yıllarda çoğunlukla mühendislik alanında kullanılan bulanık mantık, günümüzde yapay zekâ, bilgisayar, sibernetik, internet teknolojileri, yüz tanıma sistemleri, uzay araçları, evrenin oluşumu, elektron teknolojileri, robot teknolojileri, savaş teknolojileri gibi farklı alanlarda da kullanılmaktadır (Işıklı, 2008). Bulanık mantığa duyulan ilgi her geçen gün artmaktadır.

Bulanık mantığa duyulan ilgideki artış bilimsel çalışmalarda da kendini göstermektedir. 1990 yılına kadar 2361 bilimsel eserin başlık kısmında bulanık mantık ifadesi geçerken, 2003 yılı itibari ile 26680 bilimsel eserin başlığında bulanık mantık ifadesi yer almıştır (Işıklı, 2010).

Bulanık mantık mühendislik ve diğer sayısal alanların yanı sıra sosyal bilimler alanında da kullanılmaktadır. Sosyal bilimlerdeki araştırmalarda belirsizliğin olması, kesin bir dil kullanmanın sakıncaları, bulanık mantık kullanmanın önemini ortaya koymaktadır. Kesin olmayan bilgiler eşliğinde tutarlı sonuçlar çıkarabilmek için bulanık mantık yaklaşımları tercih edilmektedir (Mert \& Yılmaz, 2009). Eğitim bilimlerinde bulanık mantık çalışmaları bulunmakla birlikte eğitimde daha çok bulanık mantık daha çok ölçme, yönlendirme, zeki öğretim sistemlerinin tasarlanması, öğrenme stillerinin belirlenmesi başlıklarında çalışmalara rastlanmaktadır.

Bulanık mantığın eğitimde kullanılması ile ilgili çeşitli içerik çalışmaları bulunmaktadır. Özdemir ve diğerleri (2019), yaptıkları literatür çalışmasında eğitimde bulanık mantık ile ilgili çalışmaları incelemişlerdir. Çalışma kapsamında 2003 ile 2016 yılları arasında yapılmış 22 yüksek lisans, 6 doktora tezi incelenmiştir. Çalışmaların çoğunda bulanık mantık tabanlı bir model önermesinde bulunulduğu görülmüştür. Önerilen modellerin genellikle akademik başarı veya performans ölçme üzerine olduğu görülmektedir. Model önermenin yanında öğrenme stili belirlemede, zeki öğretim tasarımı geliştirilmesinde, uzaktan eğitim öğrencilerinin performansının belirlenmesinde bulanık mantık kullanılmıştır. Bu çalışmada incelenen çalışmaların ortak yönü olarak belirsizlik durumunda bulanık mantığın tahmin etme ve karar aşamasında başarılı sonuçlar verdiği ortaya konulmuştur. Hassas sonuçlar vermesi ve aynı anda birçok kriterin kullanılabiliyor olması bulanık mantığın avantajları olarak sayılmıştır. Çalışmalar sonucunda bulanık mantığın eğitimde kullanılmasının olumlu olduğu, bu alanda daha fazla çalışma yapılmasına ihtiyaç duyulduğu ortaya çıkmıştır (Özdemir, vd., 2019).

Sonuç olarak eğitimde akademik başarının değerlendirilmesinde, öğrenme stillerinin belirlenmesinde, performansın değerlendirilmesinde, mesleki yönlendirmede geleneksel değerlendirme sistemleri yoğun olarak kullanılmaktadır. Bunun 
yanında eğitim değerlendirmenin, sınıflamanın, karar vermenin önemli olduğu bir alandır. Eğitimde klasik değerlendirme ve karar verme mekanizmalarına alternatif olarak bulanık mantık çalışmaları da kullanılabilir. Bu çalışmada eğitimde bulanık mantık çalışmalarına değinilmiştir.

\section{2. ÇALIŞMANIN AMACI}

Eğitimde karar verme süreçlerinde öğrencinin hangi alana yöneleceğine, başarılı olup olmadığına karar vermede, performans ölçümünde birçok değişken işin içine girmektedir. Örneğin öğrencilerin akademik başarı durumlarına farklı değişkenler etki etmektedir. Akademik başarı ile tükenmişlik sendromu (Ardıç \& Polaţ̧ı, 2008), öz düzenleyici öğrenme becerileri (Turan \& Demirel, 2010), sosyo-ekonomik durum (Sirin, 2005), akademik motivasyon (Amrai vd. 2011), fiziksel aktivite (Serel, Arslan vd. 2018), probleme dayalı öğrenme yaklaşımı (Kılıç \& Moralar, 2015), bilgisayar destekli öğretim yaklaşımı (Güven \& Sülün, 2012), akademik erteleme (Balkıs vd, 2006), öz yeterlilik (Rahemi, 2007), öz düzenlemeli öğrenme (Zimmerman, 1990) gibi birçok değişken arasındaki ilişki incelenmiştir.

Bulanık mantık sistemleri yapısı gereği daha esnek sonuçlar ortaya koyabilmek ve daha doğru değerlendirmeler yapabilmek için faydalı olmaktadır. Aynı zamanda akademik başarı üzerinde etki eden değişken sayısı çok olduğundan dolayı ölçme ve değerlendirme sistemlerinde de bulanık mantıktan yararlanılmaktadır.

Bulanık mantık aynı zamanda performans değerlendirme (Çebi, 2011), zeki öğretim sistemlerinin tasarlanması (Alptekin, 2011), öğrenme stillerinin başarı ve tutuma etkisi (Özdemir, 2009), çoklu zekâ alanlarının belirlenmesi (Namlı, 2016), mesleki yönlendirme (Arı, 2009) gibi alanlarda da kullanılmaktadır.

\section{3. ÇALIŞMANIN PROBLEM DURUMU}

$\mathrm{Bu}$ araştırmada bulanık mantık yaklaşımının eğitimde hangi alanlarda hangi amaçlarla kullanıldığı araştırılmıştır. Eğitimde bulanık mantık neden ve nasıl kullanılmaktadır? Sorusuna cevap aranılan bu çalışmada aynı zamanda eğitimde bulanık mantık ile ilgili bütüncül bir bakış açısı ortaya konmaya çalışılmıştır.

\section{4. İNCELENEN ÇALIŞMALAR VE ÖZELLIKLERİ}

Alan yazın taraması şeklinde düzenlenen bu çalışmada bulanık mantık ile ilgili Science Direct, Springer, Proquest, Wiley, Emerald, Taylor Francis, Google Akademik, Dergipark, YÖK Tez Merkezi, ERIC ortamlarında eğitim ile ilgili yayınlanmış bulanık mantık çalışmaları ele alınmıştır. Toplamda 86 çalışma incelenmiştir. Bu çalışmaların 57 tanesi İngilizce, 29 tanesi Türkçe yayınlardan oluşmaktadır. Çalışmalar tür, künye, üniversitesi, ana bilim dalı, yayın yıllı, konusu, bilimsel araştırma yöntemi, örneklem düzeyi, çalışmalarda kullanılan veri toplama araçları, kaynakça sayısı, kullanılan bulanık üyelik tipi, tercih edilen durulaştırma yöntemi, kullanılan bulanık çıkarım yöntemi ve çalışmanın bulanık mantık ile ilişkisi açılarından incelenmiştir.

\subsection{Bulanık Mantık Nedir?}

Bulanık mantık bir şey hakkında verilen kararın, hangi küme elemanının ne kadar üyesi olduğunu açıklar. Bulanık mantığa göre doğruluğun ya da yanlışlğıın da bir derecesi vardır (Sıramkaya, 2019). Zadeh'e göre bulanık mantığı 3 temel üzerinde ele almak mümkündür: Mantık genişlemesi sayılabilecek bir akıl yürütmesi, bulanık kümeler vasıtası ile genişletilmiş bir bulanık mantık yorumu, en geniş anlamı ile bulanık aritmetikten bulanık biçim tanıma ve bulanık dillere kadar giden geniş bir alanda çalışılan bir alandır (Işıklı, 2010).

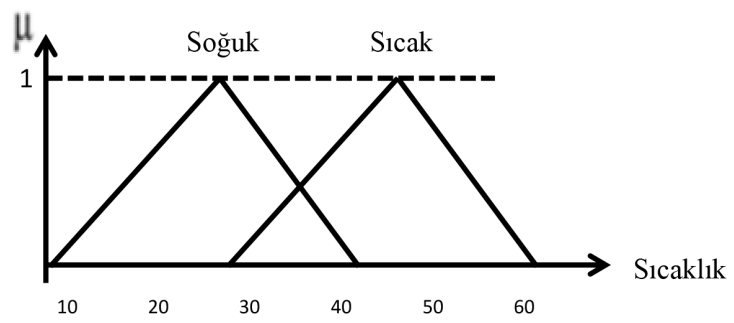

Şekil 1. Bulanık Mantık Modeli 


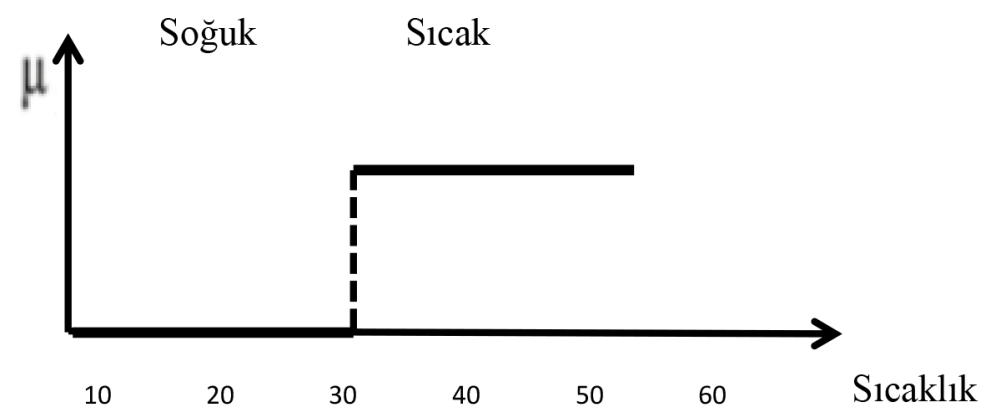

Şekil 2. Klasik Mantık Modeli

Şekil-2 incelendiğinde klasik mantığın kesin sınırları olduğu, sınırın bir tarafında bulunan bir üyenin diğer tarafı ile ilişkisinin olmadığı görülmektedir. Şekil-1 de, bulanık mantıkta her iki kümeye üye olabilen küme elemanlarını görebilmek mümkündür.

Bulanık mantığın kuramsal temelinde Aristo mantığı, bulanık mantık ayrımının yanında iki tane daha kuramsal görüş yer almaktadır. Dinamik sistemler kuramı ve soft computing kuramları bulanık mantığın kuramsal kökenlerinin oluşturulmasında önemli bir yer tutmaktadır. Doğayı modellemek için önemli bir kuram olan dinamik sistemler kuramı, dinamik birleşik sistemler yaklaşımı altında sosyal ve bilişsel problemlerin incelenebilmesini mümkün kılmaktadır. Yine dinamik sistemler kuramına göre mükemmel bir sistem oluşturmak mümkün değildir. Zadeh, bulanık mantıkta bu gerçeği, bir önermenin netleştirilmesi durumunda diğer önerme aynı derecede bulanıklaşmaktadır şeklinde ifade etmektedir. Soft computing kuramı ise yine Zadeh tarafından geliştirilen ve zeki sistemler tasarlamak için kullanılan bir kuramdır. Bu kuram farklı kuramların birbirini reddetmesi yerine birlikte kullanılmasını öneren bir sistemdir. Soft computing kuramı birçok farklı kuramın bir araya getirilmesi ile oluşturulmuş bir kuramdır (Işıklı, 2010).

Bulanık mantığın günümüzde uygulama bulduğu birçok bulanık sistem mevcuttur. Bulanık sistem ile klasik sistemin karşılaştırılması aşağıdaki şekillerde gösterilmiştir (Şen, 2001).

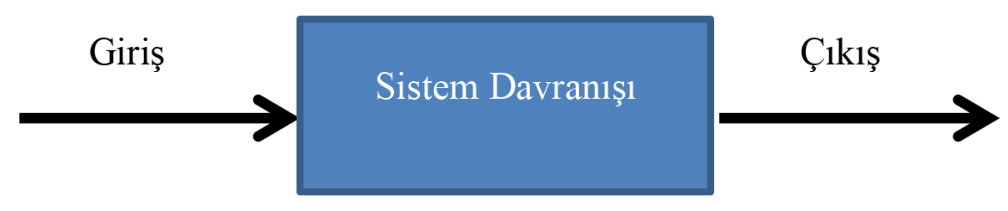

Şekil 3. Klasik Sistem

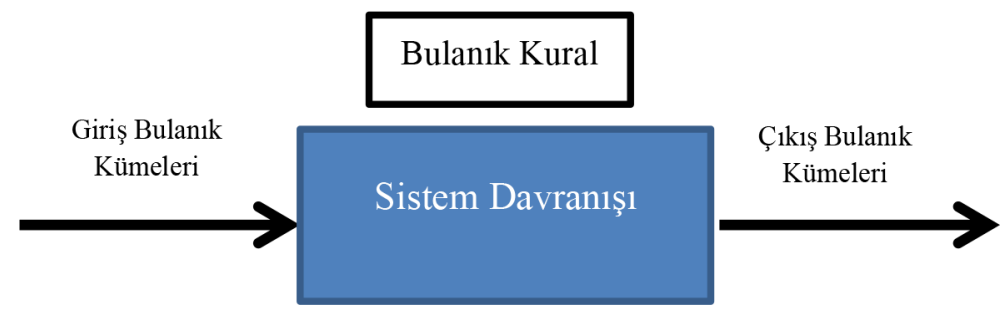

Şekil 4. Genel Bulanık Sistem

Şekil 4'te bir bulanık sistemin temel mantığı gösterilmektedir. Şekil 3’ten farklı olarak, burada girdi değerleri ve çıktı değerleri bulanık elemanlardan oluşmaktadır (Şen, 2001). Girdi değerleri üç adımda çıktı halini alır. Bu adımlar bulanıklaştırma, kontrol, durulaştırmadır.

Bulanık küme oluşturma bulanıklaştırma olarak adlandırılır. Mevcut bilgiler ve oluşturulan kurallar eşliğinde elemanlar arasında bağlantı kurma ve bu yolla bulanık kümeler oluşturmaya bulanıklaştırma süreci adı verilir Bulanık verilerin bulanık kümelerde temsil edilecek şekilde sayısallaştırılmasına davranış tanımlama adı verilir. Bulanık sayıları ve bulanık kümeleri ham sayılara dönüştürme işlemine ise netleştirme, durulaştırma adı verilir (Işıklı, 2010). 
Bulanık mantık ile ilgili en önemli kavramlardan birisi de bulanık küme kavramıdır. Bulanık küme üyelik derecelerinin sürekli olması mantığına dayanan bir nesne sınıfıdır. Böyle bir kümede kümenin elemanlarının sıfır ile bir arasında değişen üyelik dereceleri bulunmaktadır (Zadeh, 1965). Klasik küme anlayışında keskin sert sınırlar bulunmaktadır. Bulanık küme klasik kümeden nispi üyelik yönünden ayrılır. Klasik kümede var - yok ikilemi varken, bulanık kümede tam üyelik “1”, ile kümeye hiç üye olmama " 0 " ile temsil edilirken 1 ile 0 arasındaki değerler ise nispi üyelikleri ifade eder (Arslan, 2019).

Bulanık mantık ile ilgili önemli bir çalışma alanı da bulanık denetim sistemleridir. Mamdani ve arkadaşları tarafından hayata geçirilen bu sistemler birçok sektörde kullanılmaktadır. Bulanık mantık denetim sistemleri, klasik kontrol sistemlerinin daha verimli hale getirilmesi amacı ile birçok alanda karşımıza çıkmaktadır. Bulanık mantığın yapay zekâ ve genetik algoritmalar ile bir arada kullanılması ile daha akıllı, insan davranışlarına daha yakın denetim sistemleri ortaya çıkmıştır. Bulanık mantık sistemleri, daha hassas, daha fazla doğruluk payı barındıran denetim sistemleri olarak nitelenebilir (Altaş, 1999).

Bulanık denetim sistemlerinde bulanık denetleyiciler denilen yapılar kullanılır. Bulanık denetleyiciler, sonuç üretmek için bulanık kurallar adı verilen kurallar topluluğunu kullanırlar. Bunun yanında bulanık denetleyiciler, farklı üyelik fonksiyonlarını da kullanabilmektedir. Bulanık mantık ile ilgili üyelik fonksiyonları bulanık denetleyicilerin sonuç üretmesi için gereklidir. Bulanık mantık üyelik fonksiyonlarının en bilinenleri üçgen, yamuk, sinüsoid, cauchy, çan, sigmoid, gaussian şeklindedir. Bulanık mantıkta feedback (geri bildirim) mekanizması sayesinde hangi kurallar sisteminin ve hangi üyelik fonksiyonunun daha verimli sonuçlar elde ettiği görülebilir (Akyazı, Usta \& Akpınar, 2011).

Bulanık mantıkta çok kullanılan bazı üyelik tiplerinin açıklamaları aşağıdadır. Üçgen tipi üyelik fonksiyonu a ve c üçgenin tabanını, b değeri ise üçgenin tepe noktasını oluşturacak şekilde tanımlanır. Şekil 5’te üçgen tipi üyelik fonksiyonu görülmektedir (Ayçın, 2011).

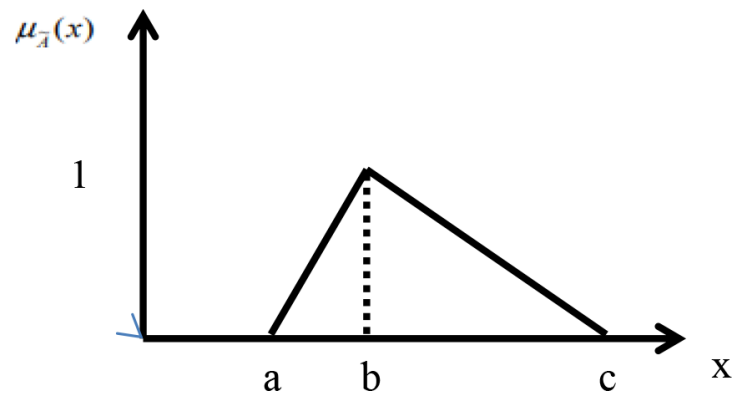

Şekil 5. Üçgen Tipi Üyelik Fonksiyonu

Yamuk üyelik fonksiyonunda alt limit olarak a, üst sınır olarak d ve öz değerler olarak da b ve d değerlerini temsil eden dört eleman bulunmaktadır. Şekil 6'da yamuk tipi üyelik fonksiyonu görülmektedir (Ayçın, 2011).

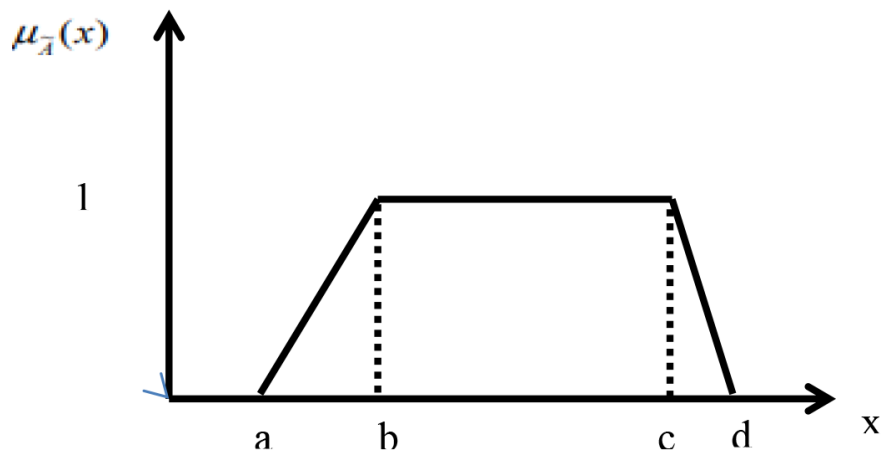

Şekil 6. Yamuk Tipi Üyelik Fonksiyonu 
Gauss Tipi üyelik fonksiyonu bir diğer üyelik fonksiyonudur. Bu üyelik fonksiyonu m ve k olmak üzere iki tane parametreye sahiptir. Burada m fonksiyonun merkez değerini, k ise genişliğini ifade etmektedir. Şekil 7'de Gauss tipi üyelik gösterilmiştir (Ayçın, 2011).

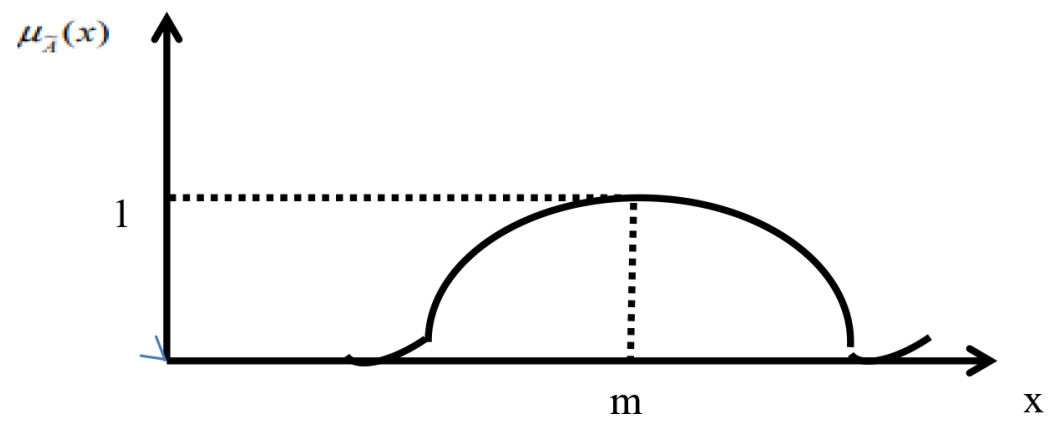

Şekil 7. Gauss Tipi Üyelik Fonksiyonu

Bulanık mantık işlemleri sonucunda sonuç elde etmek için çıkarım işlemleri uygulanır. Çıkarım işlemleri bulanık çıkarım ve durulaştırma olarak ikiye ayrılır. Bulanık çıkarım için Mamdani, Sugeno ve Tsukamoto çıkarım metotları kullanılır. Bulanık mantık her ne kadar belirsizlik ile ilintili olsa da sonuçta o da sayısal değerlere ihtiyaç duyar. Bulanık sistemin sonuçlarının sayısallaştırılması için durulaştırma yapılmaktadır.

Maksimum üyelik yöntemi, Ağırlık Merkezi Yöntemi ve Ağırlık Ortalaması Yöntemi, Mean-Max Üyelik Yöntemi, En Büyük İlk veya Son Üyelik Derecesi yöntemi durulaştırma sırasında kullanılan başlıca yöntemler arasındadır. Maksimum Üyelik ilkesinde, Üyelik derecesi en büyük olan üye kesin değer olarak kabul edilir. En Büyüklerin Ortası Yöntemi ise, üyelik derecesi en büyük olan üyelerin ortalamasının alınarak bilgilerin kesinleştirilmesine dayanan durulama ilkesidir (Alptekin, 2011).

Bulanık mantık karar verme sistemleri ile de birlikte sıklıkla kullanılmaktadır. Çok kriterli karar verme teknikleri, karar aşamasında kriter sayısının çok olduğu durumlarda tercih edilir. Birçok farklı çok kriterli karar verme tekniği bulunmaktadır. WPM, TOPSIS, PROMETHEE, AND, DEMATEL, AHP çok bilinen karar verme sistemlerinden bazılarıdır. Bulanık mantık belirsizlik durumlarında önemli avantajlar sağladığından çok kriterli karar verme teknikleri ile birlikte verimli bir şekilde kullanılabilmektedir (Şengül, Miraç \& Shıraz, 2012).

Bulanık mantığın çeşitli avantajları ve dezavantajları bulunmaktadır. Bulanık mantık insan düşünüş tarzına çok yakındır. Bulanık mantık matematiksel modellere ihtiyaç duymadığından, sözel dil yapısına daha uygun olduğundan dolayı denetim işlemlerinde daha fazla tercih edilmektedir. Sistemlerin kararlılık, gözlemlenebilirlik ve denetlenebilirlik analizlerinde kesin bir yöntemin olmaması bulanık mantığın en önemli dezavantajı olarak öne çıkmaktadır. Bulanık mantıkta üyelik işlevleri bulunmaktadır. Üyelik işlevlerinin ayarlanmasının çok zaman alması ve bulanık mantığın tek başına öğrenme yeteneğinin olmaması da önemli bir dezavantajıdır (Ayçın, 2011). Bulanık mantık esnek yapısı nedeni ile kesinlik taşımayan verileri modelleme imkânı sunar. Günlük hayatta söz ile ifade ettiğimiz olayları modelleyebilmek açısından bulanık mantık bizlere firsatlar sunar (Baykal \& Beyan, 2004).

\section{BULGULAR}

Bu çalışmada bulanık mantığın eğitimde kullanımı ile ilgili bir literatür çalışması yapılmıştır. Bulgular kısmında elde edilen sonuçlar listelenmiştir.

\subsection{Tezlerin Türlerine Göre Dağılımı}

Çalışmaları içinde tezler türlerine göre incelendiğinde Tablo 1'de 4 doktora, 18 yüksek lisans çalışması yapıldığı görülmektedir. 
Tablo 1

Tezlerin Türlerine Göre Dağılımı

\begin{tabular}{lcc} 
Türü & Frekans(f) & Yüzde(\%) \\
\hline Yüksek Lisans Tezi & 18 & 81,82 \\
Doktora Tezi & 4 & 18,18 \\
\hline Toplam & $\mathbf{2 2}$ & $\mathbf{1 0 0}$ \\
\hline
\end{tabular}

\section{2. Çalışmaların Yıllara Göre Dağılımı}

Tez çalışmaları yıllara göre incelendiğinde aşağıdaki grafik ile karşılaşılmaktadır. Grafik 1'de görüldüğü üzere tez çalışmalarında dalgalı bir seyir gözlenmektedir. En yüksek çalışmaya 2016 yılında ulaşılmıştır.

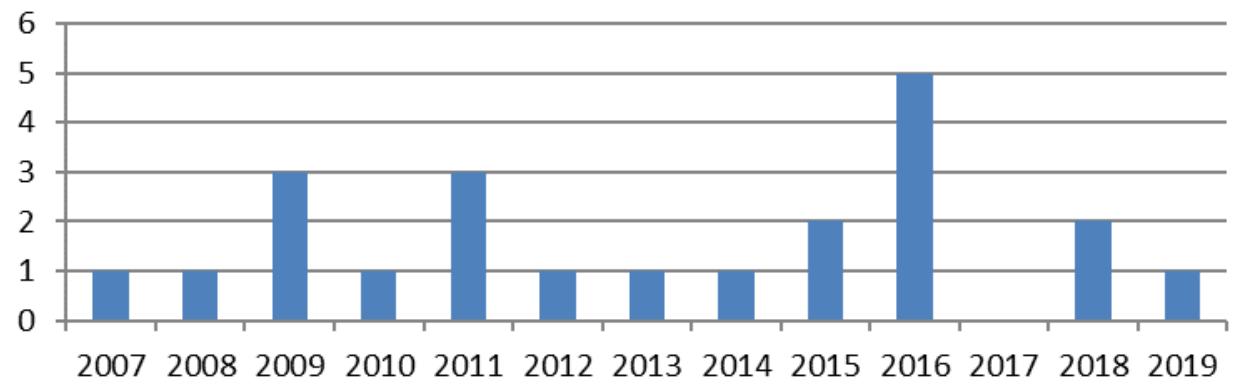

Grafik 1. Tezlerin Y1llara Göre Dağılımı

Grafik 2'de görüldüğü üzere makale çalışmaları yıllara göre incelendiğinde inişli çıkışlı bir görüntü ile karşılaşılmaktadır. Bunun yanında bulanık mantık ile ilgili makalelerin son yıllarda arttığı görülmektedir.

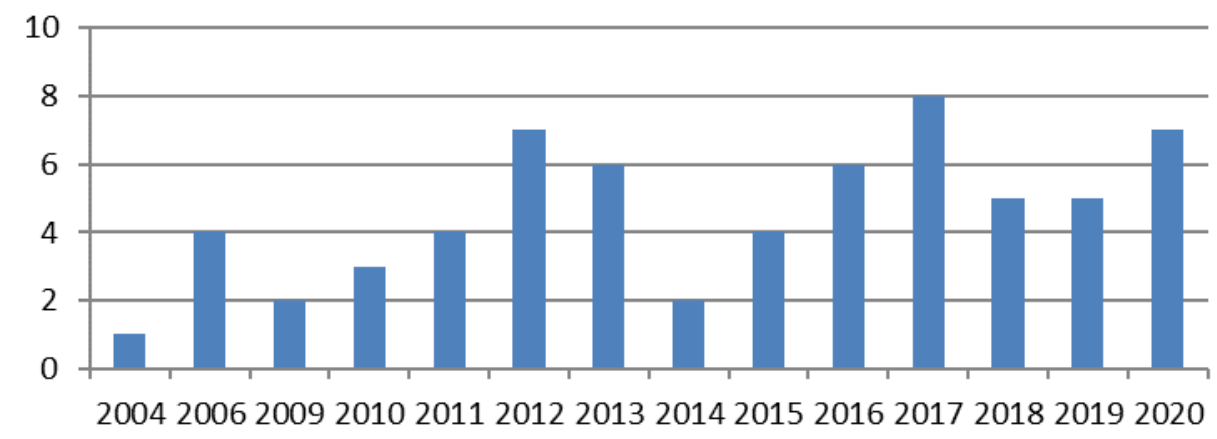

Grafik 2. Makalelerin Yıllara Göre Dağılımı

Bulanık mantık ile ilgili tez ve makalelerin yayınlanma yıllarına bakıldığında grafik 3 ile karşılaşılmaktadır. Tezlerin ve makalelerin sayısında son yıllarda artış olduğu görülmektedir.

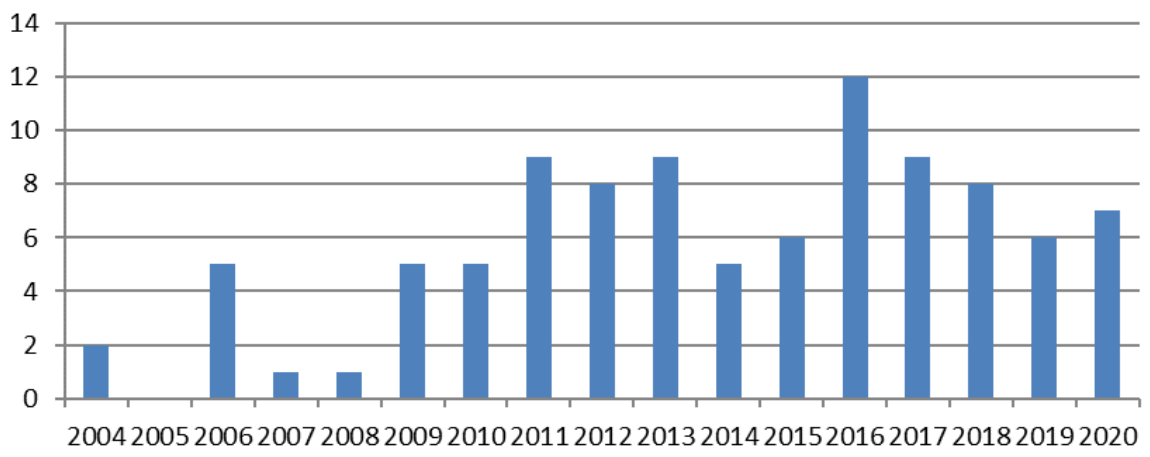

Grafik 3. Tezlerin ve Makalelerin Yıllara Göre Dağılımı 


\subsection{Tez Çalışmalarının Üniversitelere Göre Dağılımı}

Tez çalışmaları üniversitelerine göre incelendiğinde grafik 4 ile karşılaşılmaktadır. Eğitimde bulanık mantık ile ilgili en fazla çalışma Marmara Üniversitesinde yapılmıştır. Marmara Üniversitesini, Celal Bayar Üniversitesi, Fırat Üniversitesi izlemektedir.

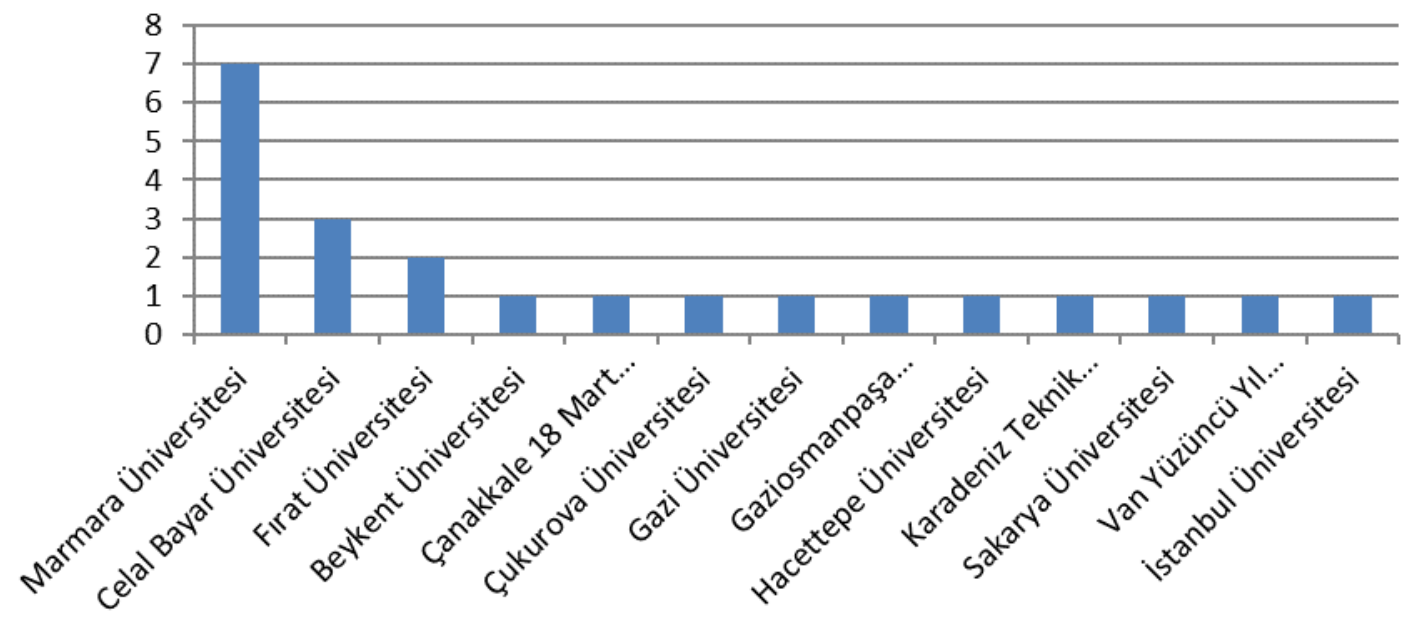

Grafik 4. Tezlerin Üniversitelere Göre Dağılımı

\subsection{Tez Çalışmalarının Anabilim Dallarına Göre Dağılımı}

Tez Çalışmaları ana bilim dallarına göre sıralandığında grafik 5 ile karşılaşılmaktadır. Görüldüğü gibi Elektronik ve Bilgisayar Eğitimi, Matematik ve Bilgisayar ve Öğretim Teknolojileri Eğitimi anabilim dallarında en çok yayın yapılmıştır.

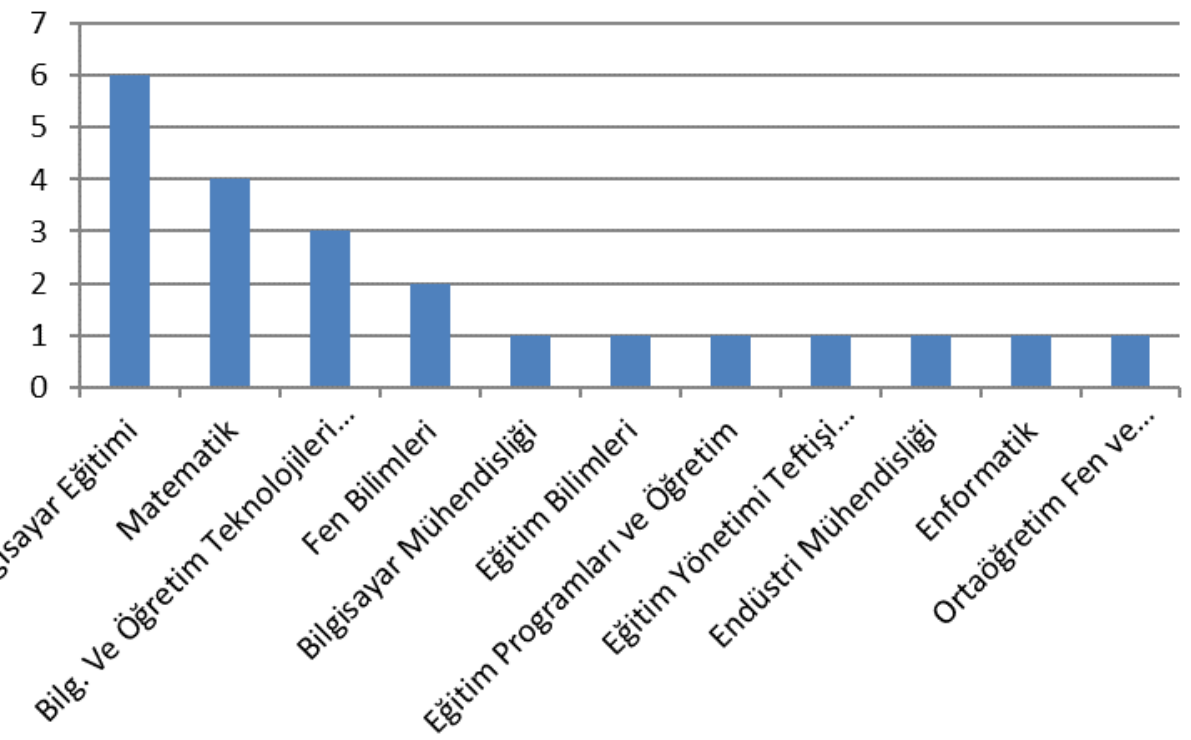

Grafik 5. Tezlerin Anabilim Dallarına Göre Dağılımı

\section{5. Çalışmaların Konularına Göre Dağılımı}

Tez Çalışmalarında incelenen konulara bakıldığında grafik 6 ile karşılaşılmaktadır. Grafikte görüldüğü üzere en fazla performans değerlendirme, başarı tespit/tahmini ve öğrenme stillerinin belirlenmesi konuları çalışılmıştır. 


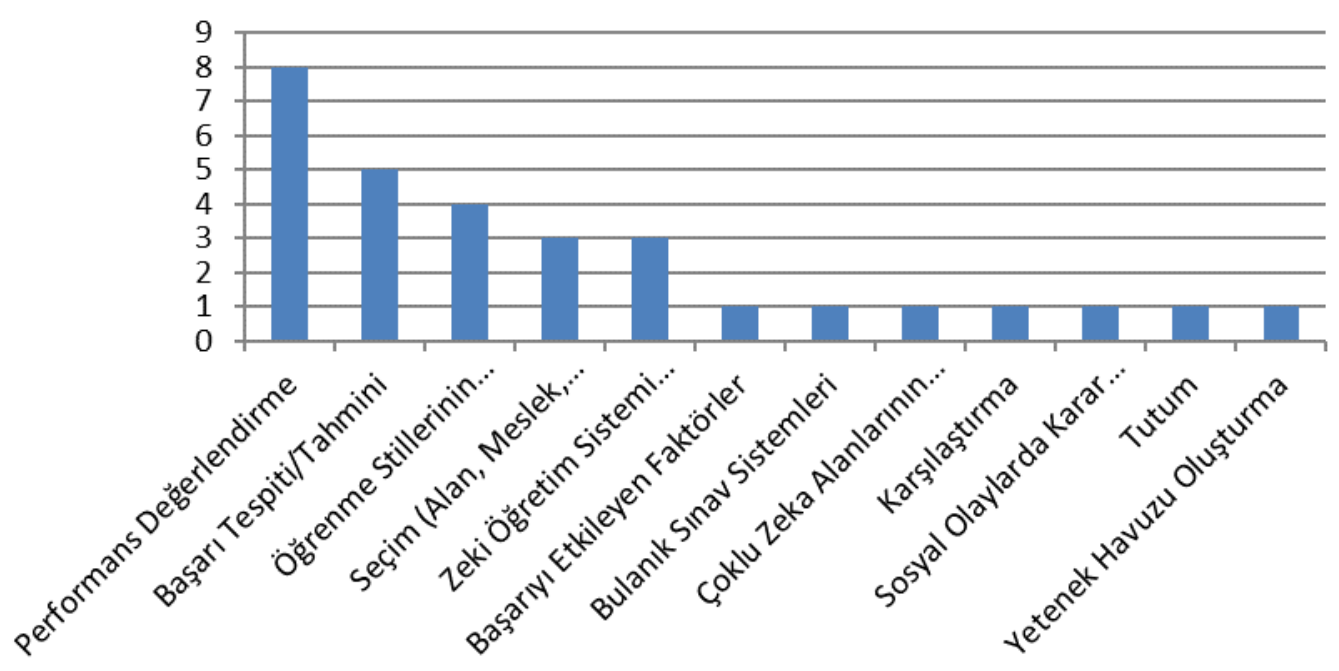

Grafik 6. Tezlerin Konularına Göre Dağılımı

Grafik 7'deki gibi makaleler konularına göre incelendiğinde performans değerlendirme, beceri, sistem değerlendirme, seçim/ karar verme, öğrenme stillerinin belirlenmesi konularında en fazla çalışma yapılmıştır.

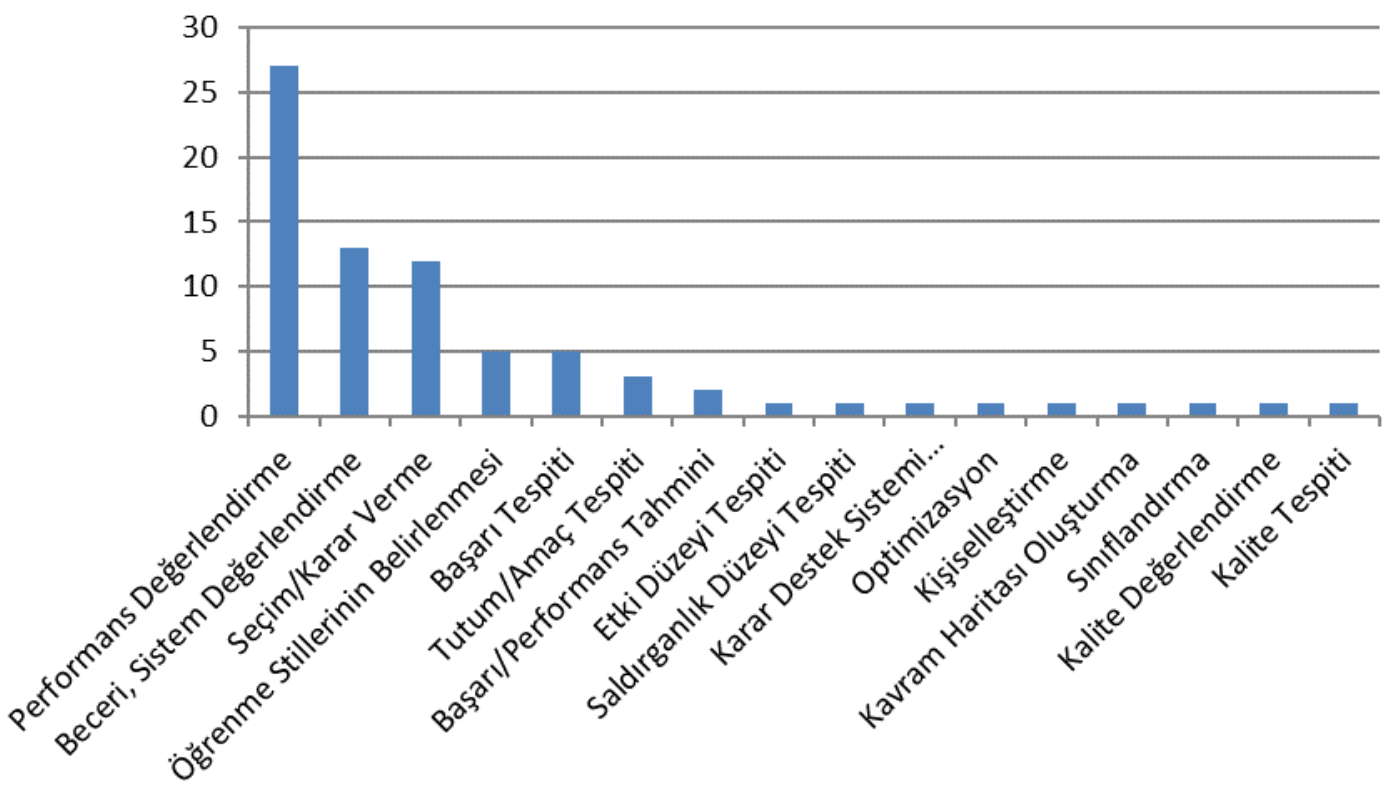

Grafik 7. Makalelerin Konularına Göre Dağılımı

\section{6. Çalışmalarda Tercih Edilen Bilimsel Araştırma Yöntemleri}

Çalışmalarda tercih edilen araştırma yöntemleri incelendiğinde grafik 8'de görüldüğü üzere en çok karma araştırma yönteminin, sonrasında ise nicel ve nitel araştırma yöntemlerinin tercih edildiği görülmüştür. 


\section{Araştırma Yöntemleri}

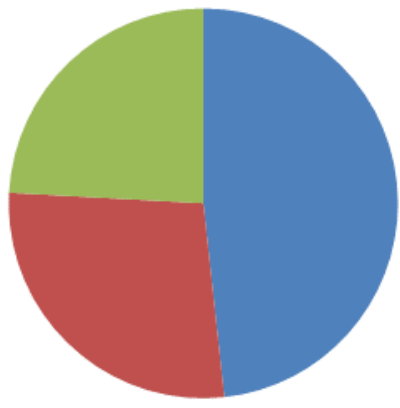

- Karma

- Nicel

Nitel

Grafik 8. Tez ve Makalelerde Kullanılan Araştırma Yöntemleri

\section{7. Çalışmalarda Kullanılan Anahtar Kelimeler}

Anahtar kelimeler ile ilgili grafik (Grafik 9) incelendiğinde en fazla kullanılan anahtar kelimeler: Bulanık mantık, eğitim, performans değerlendirme, öğrenme stilleri, çok kriterli karar verme, bulanık küme, uzaktan eğitim, akıllı eğitim sistemleri, oyun, e-öğrenme, meslek seçimi, modelleme, yapay zekâ, yükseköğretim şeklindedir.

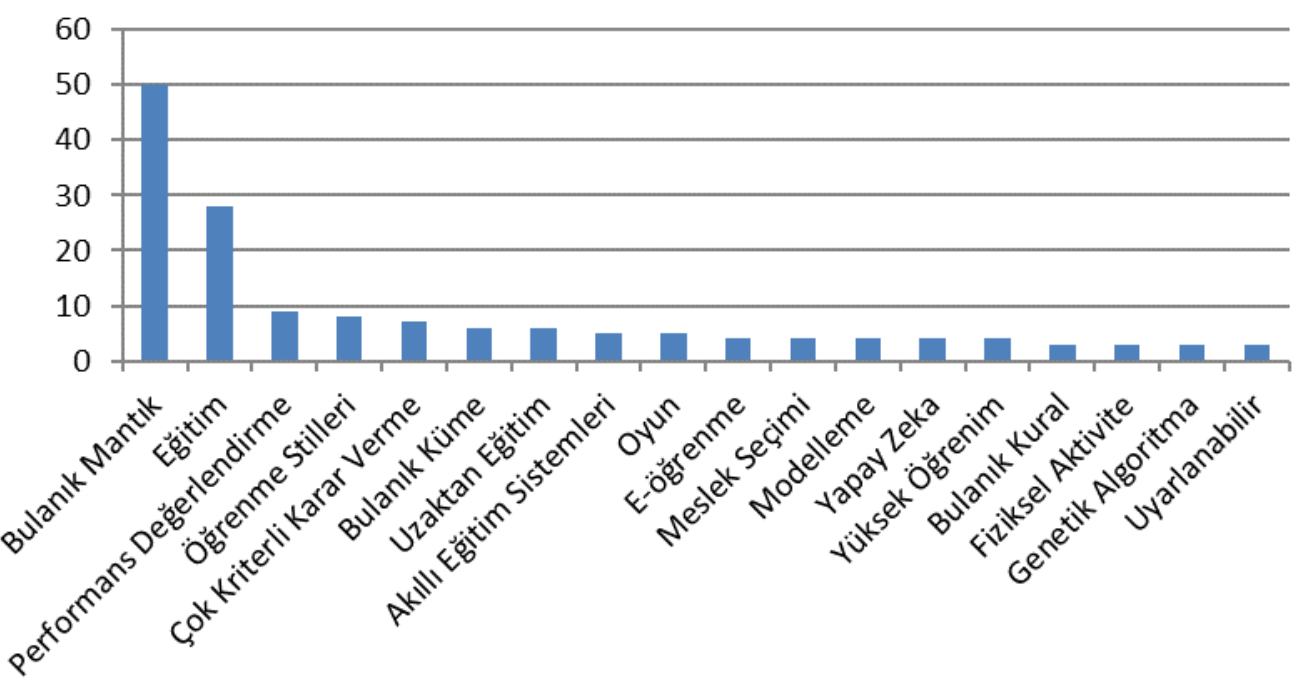

Grafik 9. Tez ve Makalelerin Anahtar Kelimelere Göre Dağılımı

\section{8. Çalışmaların Örneklem Düzeylerine Göre Dağılımı}

Örneklem düzeyleri incelendiğinde tez ve makale çalışmalarının örneklem düzeyi çoğunlukla yükseköğretim ve K-12 şeklindedir. Grafik 10’da örneklem düzeyi ile ilgili detaylar gösterilmiştir. 


\section{Örneklem Düzeyi}

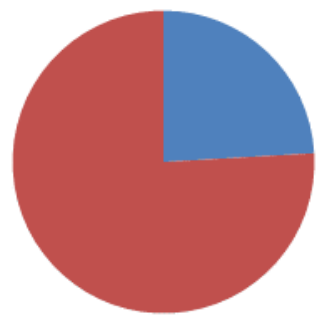

$\mathrm{K}-12$

- YÜKSEK ÖĞRETIM

Grafik 10. Çalışmaların Örneklem Düzeyine Göre Dağılımı

\section{9. Çalışmalarda Kullanılan Veri Toplama Araçları}

Veri toplama araçlarına bakıldığında çalışmalarda sıklıkla kullanılan veri toplama araçları anket, ölçek, başarı testi, değerlendirme formu ve çeşitli kayıtlar şeklindedir. Bunun dışında geliştirilen yazılımlar aracılığ edilen veri toplama aracı olarak öne çıkmaktadır. Veri toplama araçlarının pasta grafiği grafik 10'da gösterilmiştir.

\section{Veri Toplama Araçları}

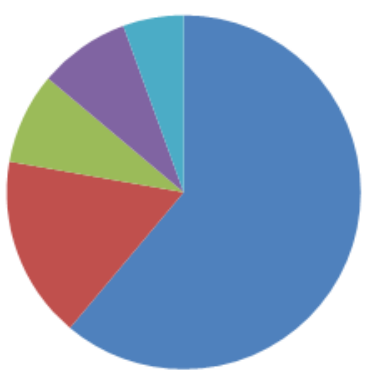

$$
\begin{aligned}
& \text { Anket } \\
& \text { Diğer araçlar } \\
& \text { Başarı Testi } \\
& \text { Ölçek } \\
& \text { Değerlendirme Formu }
\end{aligned}
$$

Grafik 10. Çalışmaların Veri Toplama Araçlarına Göre Dağılımı

\subsection{0. Çalışmalarda Tercih Edilen Örneklem Düzeyleri}

Örneklem sayısı verilen çalışmalarda en fazla 101-1000 arasında örneklem ile çalışıldığı grafik-11'de görüldüğü üzeredir. Bunun yanında bulanık mantık çalışmalarında çok daha az örneklem sayısı ile de çalışmalar yapıldığı görülebilmektedir.

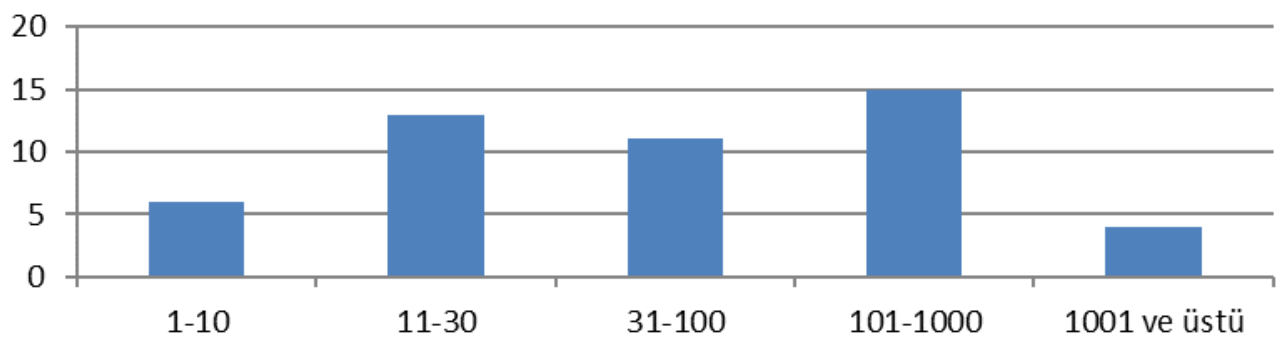

Grafik 11. Çalışmaların Örneklem Sayısına Göre Dağılımı

\subsection{1. Çalışmaların Kullanılan Kaynak Sayısına Göre Dağılımı}

Çalışmalarda kullanılan kaynakça sayılarına bakıldığında en az 6 en fazla 345 kaynakça gösterildiği görülmüştür. Grafik 12 'de görüldüğü üzere az sayıda kaynak ile de bulanık mantık çalışması yapılabilmektedir. 


\title{
Kaynakça Sayısı
}

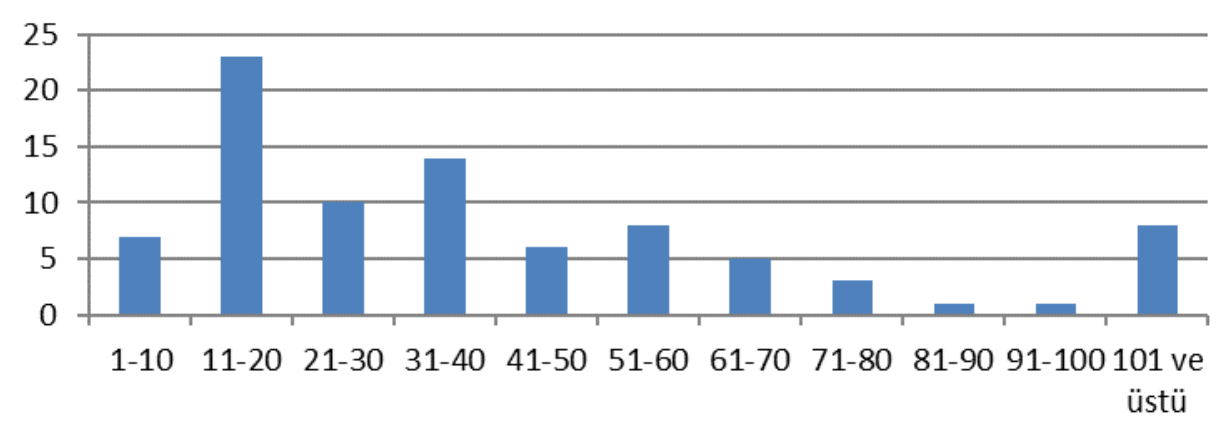

Grafik 12. Çalışmaların Kaynakça Sayısına Göre Dağılımı

\subsection{2. Çalışmalarda Kullanılan Bulanık Üyelik Tipleri}

Bulanık mantıkta üyelerin aldığı değerler ile oluşturulan eğrilere ya da çizimlere üyelik fonksiyonu adı verilir. Bu başlık altında incelenen çalışmalarda kullanılan bulanık mantık üyelik fonksiyonları incelenmiştir. Grafik 13 incelendiğinde en fazla üçgen üyelik fonksiyonunun kullanıldı̆̆ görülmektedir.

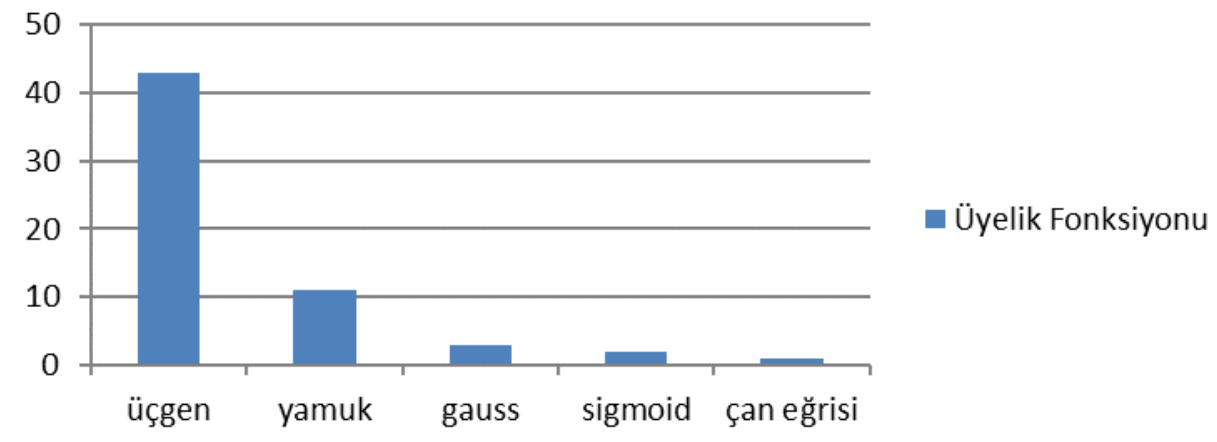

Grafik 13. Çalışmalarda Kullanılan Üyelik Fonksiyonları

\subsection{3. Çalışmalarda Kullanılan Durulaştırma Yöntemleri}

Bulanık mantık ile ilgili çalışmalara bakıldığında durulaştırma yöntemlerinin önemli yer tuttuğu görülmektedir. Çalışmalarda tercih edilen durulaştırma yöntemleri Grafik 14'de belirtilmiştir.

\section{Durulaştırma Yöntemleri}

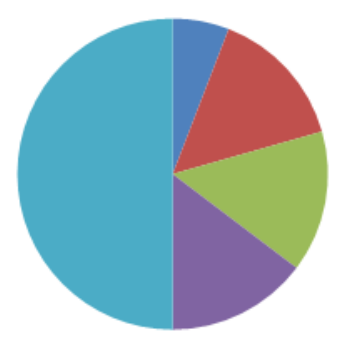

\author{
CFCS(Converting Fuzzy \\ Data İnto Crisp Scores) \\ naksimum üyelik yöntemi \\ Alan Merkezi Yöntemi
}

Grafik 14. Çalışmalarda Kullanılan Durulaştırma Yöntemleri 


\title{
5.14. Çalışmalarda Kullanılan Bulanık Çıkarım Yöntemleri
}

Literatürde sıklıkla karşılaşılan bulanık çıkarım yöntemleri Mamdani, Sugeno ve Tsukomoto şeklindedir. Bu çalışmada da kullanılan bulanık çıkarım yöntemleri incelenmiş ve sonuçlar grafik 15'de belirtilmiştir.

\section{Bulanık Çıkarım Yöntemleri}

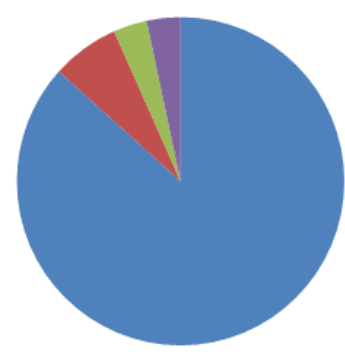

\author{
namdani Yöntemi \\ nax Dot Yöntemi \\ - Max Product Yöntemi \\ Sugeno Yöntemi
}

Grafik 15. Çalışmalarda Kullanılan Bulanık Çıkarım Yöntemleri

\subsection{Eğitimde Bulanık Mantık Kullanımı İle İlgili Yayınlar}

Bu araştırmada eğitimde bulanık mantık kullanımı ile ilgili 86 çalışma taranmıştır. Bu kısımda bu çalışmalara çeşitli başlıklar altında değinilmiştir.

\subsubsection{Zeki Sistemler}

Eğitimde bulanık mantık kullanımı ile ilgili çalışmaların bir kısmında bulanık mantığın zeki sistemler ya da zeki öğrenme sistemleri geliştirilmesinde tercih edildiği görülmektedir. Marmara Üniversitesinde yürütülen bir lisansüstü çalışmasında eğitim fakültesinde okuyan öğretmen adaylarının performanslarını inceleyen, onlara güçlü ve zayıf yönleri hakkında geri bildirimde bulunan uzman sistem oluşturulmuştur. Bulanık mantık ve grup karar destek sistemlerinin kullanıldı̆̆ çalışmada oluşturulan sistemin öğretmen adaylarının performanslarının ölçülmesinde başarılı olduğu, öğretmen adaylarına zayıf ve güçlü yanları ile ilgili geri bildirimde bulunduğu görülmüştür (Ordukaya, 2011).

Bulanık mantık yaklaşımları zeki öğretim sistemleri tasarlanmasında sıklıkla kullanılmaktadır. Karacı (2013), yaptığı çalışmada Türkçenin öğretilmesi amacı ile bir zeki öğretim sistemi tasarlamıştır. Ses sentezleme ve tanıma teknolojilerinin temel alındığı bu sistemde okuma, yazma ve dinleme etkinlikleri yer almaktadır.

Bir başka çalışmada fiziksel aktiviteleri değerlendirmek için hazırlanan bir zeki öğretim sistemi tasarımında bulanık mantık ve sinir ağlarına dayalı bir yapı kullanılmıştır (Sgrò, vd. 2010). Bu çalışmada öğrencinin fizik ya da matematik gibi farklı alanlarda olduğu gibi fiziksel çalışmalarda da kendi kendini değerlendirmesi sağlanmaya çalışılmıştır.

Bulanık mantık ile zeki öğretim sistemi tasarımı yapılan bir diğer çalışmada öğrencilerin e-öğrenme deneyimlerini kişiselleştirmek amaçlanmıştır. Bulanık tabanlı, akıllı bir e-öğrenme sistemi öneren bu çalışmada öğrencilerin kişisel öğrenme deneyimlerini yükseltmek hedeflenmiştir. Bulanık girdi birimleri olarak öğrencilerin kişisel özellikleri temel alınarak öğrencilere kişisel tavsiyelerde bulunabilen bir öğrenme ortamı tasarlanmıştır (Karthika, Deborah, \& Vijayakumar, 2019).

Proquest veri tabanında yayınlanan başka bir çalışmada zeki öğretim sistemleri sanal eğitimde kullanılmıştır. Sanal eğitimde önerilen bir sistem üzerine yapılan bu çalışmada, yapay zekâ sistemleri ile yapılacak e-öğrenme deneyimlerinin daha verimli olacağı; öğrencilerin ve grupların farklı gereksinimlerinin karşılanması için bulanık mantıktan yararlanabileceği ifade edilmektedir (Machado, vd. 2016).

Öğrencilerin İngilizce öğrenme becerileri ile ilgili başka bir çalışmada ise öğrencilere İngilizce okumalar yapmaları için makale tavsiye eden bir zeki sistem geliştirilmiştir. Bulanık mantık temelli bu sistem öğrencilerin profil bilgilerine ve önceki okumalarına bakarak, onlara uygun okuma metinleri önermektedir (Hsieh, vd. 2012). 
Alptekin, (2011) tez çalışmasında görme engelliler için zeki öğretim sistemi tasarlamıştır. Görme engellilerin herhangi ek bir araca ihtiyaç duymadan internet tabanlı bu öğretim sistemini kullanmaları amaçlanmıştır. Fare ile kontrol edilebilir ve ses ile yönetilebilir bir ara yüze sahip olan sistem, bireylerin öğrenme stillerini bir test yardımı ile tespit edip onları uygun içeriklere yönlendirmektedir.

\subsubsection{Eğitsel Oyunlar}

Bulanık mantık ve eğitsel oyunların ilişkisini inceleyen çeşitli çalışmalar da literatürde yer almaktadır. Eğitsel oyunlarda bulanık mantık kullanımı ile ilgili 4 farklı yayına rastlanılmıştır.

Mobil tabanlı bir oyun tasarımında bulanık mantıktan oyun içinde öğrencilere tavsiyede bulunan ve öğrenmelerini destekleyen bir yapı içerisinde yararlanılmıştır (Troussas, Krouska, \& Sgouropoulou, 2020). Alınan geri bildirimler, öğrenciler tarafından yapının olumlu bulunduğunu göstermektedir.

Papadimitriou ve arkadaşları (2019), bulanık mantık ile geliştirdikleri oyunda, oyunun öğrencinin bilgi seviyesine göre dinamik olarak ilerlemesini ve oyunun zorluk seviyesinin değişmesini sağlamışlardır. Uyarlanabilir yapısı ile FuzzEG isimli oyun, öğrencilerin bireysel öğrenmelerini desteklemektedir. Yine öğrencilerin gelişimlerini desteklemek için hazırlanan eğitsel çok oyunculu bir oyunda, öğrencilerin ilerlemesine bağlı olarak oyunun zorluk seviyesi ve oyunun hızı değişmektedir (Ivan, vd. 2017).

Video oyunlarında zeki sistem tasarımına yönelik bir diğer çalışmada ise kullanıcı performansını değerlendirmek ve belirli zorluklara göre ek çalışma materyali sunmak için bulanık mantıktan faydalanılmıştır (Robles \& Quintero 2020). Etkileşimli öğrenmeye olanak veren bu çalışmada video oyunlarının ve akıllı sistemlerin birlikte kullanılmasının öğrencilerin performanslarına olumlu etki ettiği görülmüştür.

\subsubsection{Performans Değerlendirme}

Bulanık mantık aynı zamanda performans belirlemede de kullanılmaktadır. Kuşçu, (2007) karar verme süreçlerinde bulanık mantık isimli çalışmasında, öğretim elemanlarının performanslarını incelemek için, bulanık tabanlı bir model geliştirmiştir. $\mathrm{Bu}$ çalışma sonunda bulanık mantığın geleneksel yöntemden daha başarılı sonuçlar verdiği, insan düşünce ve davranışlarına benzer bir şekilde bilgisayarlardan yararlanabilmeyi sağladığı görülmüştür.

Çebi, (2011) yaptığı tez çalışmasında öğrenci performanslarının değerlendirilmesinde bulanık mantık yöntemini kullanmıştır. Çalışma sonucunda bulanık mantık ile hesaplanan performans değerlerinin klasik yöntem ile hesaplanan performans değerlerinden daha hassas ve daha doğru olduğu ortaya konmuştur.

Mikro öğretimde performansın araştırıldığı bir diğer çalışmada öğrencilerin performanslarını ölçebilmek için bulanık mantık tabanlı bir yazılım geliştirilmiş̧ir. Araştırma sonucunda bulanık mantık ile performans ölçmenin adaletli, objektif ve daha doğru olduğu ortaya konulmuştur (Bakanay, 2009).

Arslan (2019), yaptı̆̆ı çalışmada öğretmen performanslarını değerlendirmek için bulanık mantıktan yararlanmıştır. Bu araştırma sonucu klasik mantık ile oluşturulan performans puanlarının bulanık mantık ile oluşturulan puanlardan daha yüksek olduğu görülmüştür.

Ertuğrul (2006), yaptığı çalışmada bulanık mantık yöntemi ile üniversite öğretim üyelerinin performansını değerlendirmiştir. Araştırma sonucunda performans değerlendirmesinde klasik mantık yerine bulanık mantık kullanılmasının daha esnek olması, sesli ifadeleri formüle edebilmeye imkân tanıması yönüyle faydalı olduğu ortaya çıkmıştır.

Öğrenci performansları ile ilgili bir diğer çalışmada bulanık mantığa dayalı çok ölçütlü karar verme mekanizmaları temel alınarak öğrencilerin performansları ölçülmeye çalışılmıştır. Araştırma sonucunda bulanık mantık yaklaşımlarının öğrencilerin değerlendirilmesinde daha adil, daha hassas ve daha nesnel sonuçlar üretebileceği ortaya çıkarılmıştır(Ayca \& Hasan, 2017). 


\subsection{4. Öğrenme Stillerinin ve Zeka Alanlarının Tespiti}

Namlı, (2016) tarafından yürütülen bir tez çalışmasında öğrencilerin başarısında bulanık mantık ile oluşturulan zekâ alanlarının etkisi incelenmiştir. Deney ve kontrol gruplu bu çalışmada deney grubunun çoklu zekâ özellikleri bulanık mantık yardımı ile tespit edildikten sonra her iki grubun başarı puanları karşılaştırılmıştır. Son test puanlarına göre her iki grubun puanlarında da anlamlı bir artış gerçekleşmiştir. Grupların son test puanları arasında anlamlı bir farklılık görülmemiştir.

Fırat Üniversitesinde gerçekleştirilen bir tez çalışmasında bulanık mantık ile tespit edilmiş öğrenme stillerine göre düzenlenmiş eğitim ortamlarının öğrenci başarısı üzerine etkileri incelenmiştir. Çalışma sonucunda kontrol ve deney gruplarının son test puanları ön test puanlarına göre anlamlı bir şekilde farklı çıkmıştır(Ozdemir, 2009).

Dunn öğrenme stili üzerine yapılan bir tez çalışmasında ise öğrenme stillerinin tespitinde bulanık mantıktan yararlanılmıştır. Öğrencilerin cinsiyeti, yaşı, bölümü, sınıfı gibi değişkenlere bağlı olarak öğrenme stillerinde farklılıklar olduğu ortaya konulmuştur(Uysal, 2016).

Benzer bir çalışmada ise Gregorc öğrenme stilleri modeli baz alınarak bulanık mantık ile öğrenme stilleri tespit edilmiştir (Ergene, 2019). Öğrenme stilleri ile ilgili bir diğer çalışmada Honey \& Mumford Ve Mccarthy Öğrenme Stili Modellerinin bulanık mantık ile gerçekleştirimi ve bunun başarıya etkileri incelenmiştir(Balbal, 2016)

Öğrenme stillerinin tespiti ile ilgili bir diğer çalışmada Felder-Silvermann öğrenme stili modeli özellikle web ortamlarında öğrenme stili tespiti için kullanılmıştır. Öğrenme stillerinin tespitinde karşılaşılan zorlukları aşmak için bulanık mantıktan yararlanılmıştır. Bulanık mantık ile önerilen modelin tahmin başarısının klasik sistemlere göre daha yüksek olduğu görülmüştür (Deborah, vd. 2015).

\subsubsection{Alana/Mesleğe Yöneltme}

Akkaş, (2018) yaptığı tez çalışmasında Lise öğrencilerinin üniversite seçimini etkileyen etmenlerin incelenmesine odaklanmıştır. Çalışma kapsamında üniversite seçimindeki belirsizliğin giderilmesi için bulanık mantıktan yararlanılmıştır. Çalışma sonucunda öğrencilerin üniversite seçimi ile ilgili algılarının her sene farklılaştığ 1 görülmüştür.

Karar alırken de bulanık mantık faydalı olmaktadır. Meslek seçiminde yönlendirme yapılması amacı ile bulanık mantık temelli bir yazılım hazırlanması Sakarya Üniversitesinde bir tezin konusunu oluşturmuştur (Arı, 2009). Giriş değerleri olarak öğrenci akademik benlik değerleri ve öğrencilerin notları alınmış olup, çıktı değerleri olarak öğrencinin hangi alanda başarılı olacağına yönelik varsayımlar yer almaktadır.

Bulanık mantık öğrencileri alana yöneltmede de kullanılmaktadır. Uzun, (2008) yaptığı çalışmada ortaöğretim öğrencilerinin alana yöneltmede bulanık mantık tabanlı bir model geliştirmiştir. Çalışma sonucunda bulanık tabanlı model ile alana yönlendirmenin geleneksel yöntemlere göre daha başarılı olduğu, bu başarısının altında yatan nedenin bulanık mantığın çok kriterli karar vermeye müsait olmasından kaynaklandığı, bulanık mantık sayesinde eğitimde rehberlik işlemlerinde karmaşık hesaplamaların hızlıca yapılmasına imkân tanıdığı görülmüştür.

\subsubsection{Başarı/Performans Tahmini}

BÖTE öğrencilerinin başarı durumlarının incelendiği bir tez çalışmasında Bilgisayar ve Öğretim Teknolojileri Eğitimi Bölümü öğrencilerinin akademik başarılarını etkileyen faktörleri belirlemek ve böylelikle akademik başarıyı tahmin eden bir model geliştirmek hedeflenmiştir. Çalışma kapsamında öğrencilerin başarılarını etkileyen faktörler belirlendikten sonra, elde edilen verilere dayanılarak başarı tahmin modeli geliştirilmiştir. Bulanık mantık temelli geliştirilen başarı tahmin modeli yüksek düzeyde başarı sağlamıştır(Uysal, 2015).

Bulanık mantık başarı tahmininde farklı şekillerde kullanılmaktadır. (Yıldız, Bal, \& Gulseçen, 2013) yaptıkları çalışmada uzaktan eğitim öğrencilerinin yılsonu başarı notları bulanık mantık yöntemi kullanılarak tahmin edilmeye çalışılmıştır. Bu çalışmada farklı tahmin araçları karşılaştırılmıştır. İlk 8 haftanın verilerine dayanılarak yapılan tahmin çalışmalarında gen bulanık model kullanılarak yapılan tahminlerin başarılı sonuçlar verdiği görülmüştür. 
Eğitimde oyunlaştırma ile ilgili farklı bir çalı̧̧mada öğrencilerin eğitimsel öğrenme performansı bulanık mantık yardımı ile tahmin edilmeye çalışılmıştır. Çalışma kapsamında önerilen model, klasik sistemlere nazaran daha iyi sonuçlar verirken, oyunlaştırma kapsamında da hangi değişkenlerin doğru tahminler için önemli olduğunu ortaya çıkarmıştır (Su, 2017).

\subsubsection{Başarı/Yetenek/Tutum Gibi Değişkenlerin Tespiti}

Başarı değerlendirilmesinin amaçlandığı bir diğer tez çalışmasında ise ortaöğretim matematik bölümünde okuyan öğretmen adaylarının başarılarının bulanık mantık ile tespiti amaçlanmıştır. Öğretmen adaylarının başarı durumları geleneksel yöntemle ve bulanık mantık yöntemi ile tespit edilip her iki durum karşılaştııılmışıı. Bulanık mantık yöntemi ile hesaplanan başarı puanlarının geleneksel yöntem ile hesaplanan başarı puanlarından anlamlı olarak farklılaştığı, bulanık mantık ile yapılan hesaplamada öğrencilerin daha başarılı olduğu görülmüştür(Öcal, 2015).

Demirçelik, (2010) çalışmasında bulanık sınav sistemlerini incelemiş, yeni bir bulanık sınav sistemi tasarlamıştır. Tasarlanan sınav sisteminde her sorunun kolay ve zor olmak üzere çeşitli varyasyonları yer almakta olup, farklı kapasitedeki öğrencilerin çözebileceği sorular yer almaktadır. Bu çalışmada amaç farklı öğrencileri kendi seviyelerinde ölçmektir.

Gündüzalp, (2016) çalışmasında üniversite öğrencileri için yetenek yönetim havuzu oluşturmuştur. Çalışma sonucunda üniversitelerde yetenek yönetim sistemlerinin kullanılmasının faydalı olacağı, yetenek kriterlerinin bulanık mantık ile kolaylıkla işlenebileceği görülmüştür.

Güner ve Çomak (2014) yaptıkları çalışmada lise öğrencilerinin matematik dersine karşı tutumlarına etki eden değişkenleri tespit edebilmek için bulanık mantıktan yararlanmışlardır. Bu çalışmada öğrencilerin matematik dersine yönelik tutumlarını tespit etmek amacıyla oluşturulmuş bir ölçme aracının bulanık mantık yardımı ile daha hassas hale getirilmesi amaçlanmıştır. Çalışma sonucunda öğrencilerin tutum puanlarının orta düzeyde olduğu görülmüştür.

Bir araştırmada öğrencilerin teknoloji kullanımın öğrencilerin saldırganlık düzeyi ve anksiyete durumlarına etkisi bulanık mantık yöntemi ile incelenmiştir. Araştırma sonucunda saldırganlık düzeylerinin ve anksiyete durumlarının tespiti için daha güvenilir bir model ortaya konulmuştur (Memmedova, 2017).

Farklı bir çalışmada ise öğrencilerin sunum becerilerini ölçmek için bulanık mantık ile önerilen bir sistem denenmiştir. Öğrencilerin normal beceri puanları ile bulanık mantık sisteminden elde edilen puanlar karşılaştıııldığında arada anlamlı bir farkl111k olduğu görülmüştür( Ozdemir, \& Tekin, 2016)

Bir diğer çalışmada ise geleneksel sistemdeki başarı notları ve bulanık mantık ile hesaplanmış başarı notları karşılaştırılmıştır. Araştırma sonucunda bulanık mantık ile hesaplanmış başarı notlarının geleneksel sistem ile hesaplanmış başarı notlarından anlamlı derecede farklı olduğu görülmüştür. Ayrıca araştırma sonucunda bulanık mantığın derinleme öğrenme imkânı sağladığı, inceleme kaygısını azalttı̆̆ı, ayrıntılı ölçme ve değerlendirme imkânı sunduğu, sınıftaki ortalama başarıyı arttırarak homojen bir dağılım sağladığı görülmüştür(Semerci, 2004).

\subsubsection{Seçim ve Karar Destek Sistemleri}

Bulanık mantık seçme görevlerinde başarıyla uygulanmaktadır. En uygun e-öğrenme hizmet sağlayıcısını seçmek amacıyla yapılan bir çalışmada bulanık mantığa dayalı kalite işlev dağıtımı kullanılmıştır. Bu yöntem sayesinde e öğrenme hizmet sağlayıcıları için, başarı kriterleri ortaya konulmuştur(Kazançoğlu \& Aksoy, 2011).

Hizmet kalite değerlendirmesi ve seçim probleminin temel alındığı bir diğer çalışmada (Karakış, 2018), değerlendirme ve seçim için bulanık analitik hiyerarşi süreci ve MOORA yöntemleri kullanılmıştır. Çalışmanın sonucunda öğretmenlerin mesleki nitelikleri ve tecrübeleri, okuldaki eğitsel, sosyal ve kültürel faaliyetler ve okulun fiziksel özellikleri ve temizliği kriterleri performans açısından önemli kriterler olarak ön plana çıkmıştır.

Erasmus Öğrenci Değişim programlarına öğrenci seçiminde bulanık mantık yaklaşımını esas alan bir çalışmada Bulanık Analitik Hiyerarşi Süreci ve rubrik ile elde edilen puanlar karşılaştırılmıştır. İki yaklaşım sonucunda öğrenci sıralamalarının farklı olduğu, bulanık mantık yaklaşımının daha hassas ve esnek olduğu görülmüştür(Taşkın, Üstün \& Deliktaş, 2013). 


\section{TARTIŞMA VE SONUÇ}

Bu çalışmada eğitimde bulanık mantık ile ilgili çalışmalar incelenmiştir. Toplamda 86 makale ve tez incelemeye dâhil edilmiştir. İncelenen tezlerin 18 tanesi yüksek lisans tezi 4 tanesi doktora tezidir. Çalışmaların 57 tanesi İngilizce, 29 tanesi ise Türkçe yayınlardır.

İncelenen en eski çalışma 2004 yılına ait olup, bir makale çalışmasıdır. En güncel çalışma ise 2020 yılında yayınlanan bir makale çalışmasıdır. Eğitimde bulanık mantık ile ilgili yayınlarda 2009 yılından itibaren göreceli bir artış görülmektedir. Bunun nedeni eğitimde bulanık mantık kullanımının son on yıldır daha popüler hale gelmiş olması olabilir.

Tez çalışmaları yapıldığ 1 üniversitelere göre incelendiğinde en fazla Marmara Üniversitesi’nde ( 7 tez çalışması) çalışma yapıldığı görülmektedir. Marmara Üniversitesini Celal Bayar Üniversitesi ve Firat Üniversitesi izlemektedir.

Tez çalışmaları ana bilim dallarına göre incelendiğinde en fazla Elektronik ve Bilgisayar Eğitimi Anabilim Dalı, Matematik Anabilim Dalı ve Bilgisayar ve Öğretim Teknolojileri Eğitimi Anabilim dallarında çalışma yapıldığı görülmüştür. Bulanık mantı̆̆ın matematiksel kökenleri, eğitimde uygulanabilir olması, günümüzün popüler teknolojilerinden yapay zeka teknolojileri ile ilintili olması, bu anabilim dallarında yoğun bir şekilde kullanılmasına neden olmuştur.

Çalışma kapsamında tezler ve makaleler konularına göre incelenmiş̧, en fazla tercih edilen konuların performans değerlendirme, başarı tespiti/tahmini, öğrenme stillerinin belirlenmesi, seçim/karar verme olduğu görülmüştür. Çalışmaların konu alanlarına bakıldığında bulanık mantığın eğitimde karar verme, tahminde bulunma, seçim yapma, değerlendirme aşamalarında sıklıkla kullanılabildiği görülmektedir. İncelenen makalelerin konularına bakıldığında performans değerlendirme, beceri/sistem değerlendirme, seçim-karar verme olduğu görülmektedir. Makalelerde öğrenme stillerinin belirlenmesi de önemli bir konu olarak öne çıkmıştır.

Çalışmalarda kullanılan araştırma yöntemleri incelendiğinde en fazla karma araştırma yönteminin kullanıldığı görülmektedir. Bunun nedeni olarak bulanık mantığın insanlara özgü sözlü ifadeleri matematiksel olarak ifade etmek için önemli bir araç olması gösterilebilir.

Kullanılan anahtar kelimeler konularla benzer özellikler taşımaktadır. Çalışmalarda en çok bulanık mantık, eğitim, performans değerlendirme, öğrenme stilleri, çok kriterli karar verme, bulanık küme, uzaktan eğitim, akıllı eğitim sistemleri, oyun, eöğrenme, meslek seçimi, modelleme, yapay zekâ, yükseköğretim anahtar kelimeleri kullanılmıştır. Anahtar kelimelerden çıkan sonuca göre bulanık mantığın birçok farklı alanla ilişkisi olduğu görülmektedir.

Örneklem düzeyi incelendiğinde çoğunlukla yükseköğretimin tercih edildiği, bunun yanında ilk ve ortaöğretim seviyesinde çalışma sayısının az olduğu görülmektedir. Araştırmacıların yükseköğretim öğrencilerine kolay erişebilmesi, k-12 seviyesinde yapılan çalışmalarda izin alınması için gerekli prosedürel zorluklar nedenler arasında sayılabilir.

Çalışmalarda kullanılan veri toplama araçları incelendiğinde birçok çalışmada anket, ölçek başarı testi, değerlendirme veri toplama araçları kullanılmıştır. Bu sayılan veri toplama araçlarının yanı sıra bulanık mantık ile yapılan çalışmalarının neredeyse tamamında bir yazılım kullanıldığından bu yazılımlar aracılığı ile de veri toplanmaktadır.

Örneklem grupları incelendiğinde çoğunlukla 101-1000 arasında örneklem ile yapılan çalışmalar daha çoktur. Bunun yanında bulanık mantık çalışmalarında az sayıda örneklem ile yapılan çalışmalara da rastlanmaktadır. Bulanık mantıkta az sayıda kişi ile yapılan çalışmalar genel olarak vaka çalışmaları ve modelin sınanması şeklinde çalışmalardır. Aynı zamanda veri tabanları üzerinden çok sayıda kişiye ulaşarak da çalışmalar yürütülmüştür.

Çalışmalarda kullanılan kaynakça sayıları incelendiğinde çoğunlukla 11-20 arasında kaynak ile araştırmalar yapıldı̆̆ görülmektedir. Eğitim bilimlerinde yapılan diğer çalışmalar incelendiğinde bulanık mantık ile ilgili çalışmalarda kullanılan kaynakça sayısının nispeten daha az olduğu söylenebilir.

Eğitim bilimlerinde bulanık mantık çalışmalarında kullanılan üyelik fonksiyonları arasında en çok tercih edilen üçgen tipi üyelik fonksiyonu olmuştur. Üçgen üyelik tipi yapıca daha basit olduğundan daha fazla hesaplama gücü gerektirmez, bu nedenle fazlaca tercih edilmiştir. 
Eğitimde bulanık mantık ile ilgili çalışmalara bakıldığında en çok tercih edilen durulaştırma yöntemlerinin ağırlık merkezi yöntemi, ağırlık ortalaması yöntemi, alan merkezi yöntemi ve maksimum üyelik yöntemi olduğu görülmektedir. Belirlenen noktaların ağırlıklı ortalamasının alındığı; A ğırlık merkezi yöntemi bulanık mantık çalışmalarında en yaygın olarak kullanılan durulaştırma yöntemi olduğundan dolayı, eğitim bilimleri çalışmalarında da en fazla tercih edilen bulanıklaştırma yöntemi olarak öne çıkmıştır.

Bulanık mantıkta sayısal değerler elde edebilmek için bulanık çıkarım yöntemleri kullanılır. İncelenen çalışmalarda Mamdani yöntemi en fazla kullanılan bulanık çıkarım yöntemi olarak öne çıkmaktadır. Mamdani çıkarım yöntemi bulanık mantık ile ilgili tüm çalışmalarda da en fazla tercih edilen yöntemdir.

Eğitimde bulanık mantık ile ilgili çalışmalar incelendiğinde şu çıkarımlara ulaşılmıştır:

1- Eğitimde bulanık mantık ile ilgili çalışmalar belirli alanlarda yoğunlaşmıştır.

2- Eğitim süreçlerinde karar verme aşamalarında bulanık mantıktan yararlanılmaktadır.

3- Eğitimde kesin sınırları konulmamış, öğrenme stilleri, zeka alanları gibi kavramların sınırlarını daha hassas bir şekilde ortaya koyabilmek için bulanık mantıktan yararlanılmıştır.

4- Çalı̧̧maların bir kısmında klasik mantık ve bulanık mantık karşılaştıılması yapılmıştır. Bu karşılaştırmaların çoğunda bulanık mantı̆̆ın klasik mantığa üstünlükleri göze çarparken, bazı çalışmalarda bulanık mantık kullanmanın klasik mantık kullanma karşısında önemli bir üstünlüğünün olmadığı görülmüştür.

5- Çalışmalar çoğunlukla yükseköğretim seviyesinde gerçekleştirilmiştir. Benzer çalışmaların ilköğretim ve ortaöğretim seviyesinde daha fazla gerçekleştirilmesi faydalı olacaktır. Çünkü seçim karar verme mekanizmaları ilköğretim seviyesinde de gerçekleşmektedir. Örneğin Bilim Sanat merkezlerine öğrenci seçerken ya da ortaokul sonunda liseye yöneltmede bulanık mantık karar verme yaklaşımları esas alınarak daha doğru kararlar alınabilir.

6- Bulanık mantık ile ilgili bazı alanlara yoğunlaşılmıştır. Eğitimde bulanık mantık ile ilgili araştırma yapacak araştırmacıların konu seçiminde ve örneklem seçiminde bu çalışmanın sonuçlarını dikkate almaları faydalarına olacaktır. Araştırmacıların yoğunlaşılan alanlar yerine daha az araştırma yapılan alanlara yönelmesi bilime katkı açısından önemlidir.

7- Eğitimde bulanık mantık ile ilgili çalışmalara bakıldığında dezavantajlı bireyler ile çalışmaların yetersiz olduğu görülmektedir. Eğitimde bulanık mantık ile ilgili çalışmalarda bu alanda yapılacak çalışmalar daha fazla öneme sahip olabilir.

8- Eğitimde bulanık mantık çalışmalarının bir kısmında çok az sayıda örneklem ile çalışmalar yapıldığı görülmüşstür. Bu nedenle daha çok örneklem grubu ile bu çalışmalar tekrarlanabilir.

9- Bulanık mantık sistemlerinin eğitimde kullanılması ile ilgili çalışmalar bakıldığında zeki öğretim sistemlerinin yeterince çalışılmadığı görülmektedir. Araştırmacıların bu alana yönelmesi faydalı olacaktır.

10-Bulanık mantık aynı zamanda eğitsel oyunlarda eğlenceli, kişiye özgü, farklı öğrenme hızlarına uygun ortamlar tasarlamak için kullanılmaktadır. Bu nedenle eğitsel oyun tasarlayanların bulanık mantıktan yararlanmaları faydalı olacaktır.

Hakem Değerlendirmesi: Dış bağımsız.

Çıkar Çatışması: Yazarlar çıkar çatışması bildirmemiştir.

Finansal Destek: Yazarlar bu çalışma için finansal destek almadığını beyan etmiştir.

Peer-review: Externally peer-reviewed.

Conflict of Interest: The authors have no conflict of interest to declare.

Grant Support: The authors declared that this study has received no financial support. 


\section{Kaynaklar/References}

Akkaş, E. (2018). Farklı sınıf düzeyindeki lise öğrencileri arasında bulanık ahp yöntemi uygulanarak üniversite seçim kriterlerinin karşılaştırmalı analizi. Marmara Üniversitesi, Endüstri Mühendisliği,Yüksek Lisans Tezi.

Akyazı, Ö., Usta, M. A., \& Akpınar, A. S. (2011). Kapalı ortam sıcaklık ve nem denetiminin farklı bulanık üyelik fonksiyonları kullanılarak gerçekleştirilmesi. 6th International Advanced Technologies Symposium (IATS'11) (pp. 16-18).

Alptekin, N., \& Yeşilaydın, G. (2015). OECD ülkelerinin sağlık göstergelerine göre bulanık kümeleme analizi ile sınıflandırılması. Işsletme Araştırmaları Dergisi, 7(4), 137-155.

Alptekin, O. (2011). Görme engelliler için zeki bir öğretim sistemi tasarımı., Beykent Üniversitesi, Fen Bilimleri Enstitüsü, Bilgisayar Mühendisliği Anabilim Dalı, Yüksek Lisans Tezi

Altaş, İ. H. (1999). Bulanık mantık: bulanıklılık kavramı. Enerji, Elektrik, Elektromekanik-3e, 62, 80-85.

Amrai, K., Motlagh, S. E., Zalani, H. A., \& Parhon, H. (2011). The relationship between academic motivation and academic achievement students. ProcediaSocial and Behavioral Sciences, 15, 399-402.

Ardıç, K., \& Polatçı, S. (2008). Tükenmişlik sendromu akademisyenler üzerinde bir uygulama (GOÜ Örneği). Gazi Universitesi Iktisadi ve Idari Bilimler Fakultesi Dergisi, 10(2).

Arı, E. (2009). Bulanık mantık tabanlı mesleki yönlendirme. Sakarya Üniversitesi, Fen Bilimleri Enstitüsü, Yüksek Lisans Tezi.

Arslan, S. S., Alemdaroğlu, İ., Öksüz, Ç., Karaduman, A. A., \& Yılmaz, Ö. T. (2018). Genç bireylerde fiziksel aktivitenin akademik başarı ve depresyon üzerine etkisi. Ergoterapi ve Rehabilitasyon Dergisi, 6(1), 37-42.

Arslan, M. (2019). Öğretmen performanslarının bulanık mantık yöntemi ile değerlendirilmesi. Van Yüzüncü Yı1 Üniversitesi, Eğitim Bilimleri Anabilim Dalı,Yüksek Lisans Tezi.

Ayçın, E. (2011). Kural tabanlı bulanık modelleme ve fiyat tahminleme sürecinde bir uygulama. Dokuz Eylül Üniversitesi, Sosyal Bilimler Enstitüsü, İşletme Anabilim Dalı, Yönetim Bilimleri Bilim Dalı, Yüksek Lisans Tezi.

Bakanay, D. (2009). Mikro öğretimde performansın bulanık mantık yöntemiyle değerlendirilmesi. Marmara Üniversitesi, Fen Bilimleri Enstitüsü, Elektronik ve Bilgisayar Eğitimi Anabilim Dalı, Yüksek Lisans Tezi.

Balbal, K. F. (2016). Honey \& mumford ve mccarthy ögrenme stili modellerinin bulanık mantık tabanlı gerçekleştirimi ve performans analizi. Celal Bayar Üniversitesi, Fen Bilimleri Enstitüsü, Yüksek Lisans Tezi.

Balkır, Z. G., Alnıçık, U., \& Apaydın, E. (2011). Fuzzy logic in legal education. Turkish Online Journal of Distance Education, 12 (2), 60-69.

Balkıs, M., Duru, E., Buluş, M., \& Duru, S. (2006). Üniversite ögrencilerinde akademik erteleme eğiliminin çeşitli değişkenler açısından incelenmesi. Ege Ĕgitim Dergisi, 7(2), 57-73.

Baykal, N., \& Beyan, T. (2004). Bulanık mantık ilke ve temelleri. Ankara, Türkiye: Bıçaklar Kitabevi.

Çebi, A. (2011). Bulanık çok kriterli karar verme yöntemleri ile öğrenci performanslarının değerlendirilmesi. Karadeniz Teknik Üniversitesi, Eğitim Bilimleri Enstitüsü, Bilgisayar ve Öğretim Teknolojileri Eğitimi Ana bilim dalı, Yüksek Lisans Tezi.

Çebi, A., \& Karal, H. (2017). An application of fuzzy analytic hierarchy process (FAHP) for evaluating students' project. Educational Research and Reviews, 12(3), 120-132.

Çetinkaya, Ş. (2015). Stochastic mortality using non - life methods. Doğuş Üniversitesi,

Sosyal Bilimler Enstitüsü, Finansal İktisat Anabilim Dalı, Doktora Tezi.

Deborah, L. J., Sathiyaseelan, R., Audithan, S., \& Vijayakumar, P. (2015). Fuzzy-logic based learning style prediction in e-learning using web interface information. Sadhana, 40(2), 379-394.

Demirçelik, Ç. (2010). Bulanık sınav sistemleri. Gaziosmanpaşa Üniversitesi, Fen Bilimleri Enstitüsü, Matematik Anabiilim Dalı, Yüksek Lisans Tezi

Ergene, V. Ç. (2019). Bulanık mantık tabanlı gregorc öğrenme stili modeli gerçekleştirimi. Manisa Celal Bayar Üniversitesi, Fen Bilimleri Enstitüsü, Yüksek Lisans Tezi.

Ertuğrul, İ. (2006). Akademik performans değerlendirmede bulanık mantık yaklaşımı. Atatürk Üniversitesi İktisadi ve İdari Bilimler Dergisi 20(1): $155-76$.

Gündüzalp, S. (2016). Üniversitelerde yetenek yönetimi kapsamında yetenek havuzu oluşturmaya yönelik bir model önerisi. Fırat Üniversitesi, Eğitim Bilimleri Enstitüsü, Doktora Tezi.

Güner, N., \& Çomak, E. (2014). Lise öğrencilerinin matematik dersine yönelik tutumlarının bulanık mantık yöntemi ile incelenmesi. Pamukkale Üniversitesi, Mühendislik Bilimleri Dergisi, 20(5), 189-196.

Işıklı, Ş. (2008). Bulanık mantık ve bulanık teknolojiler. Araştırma Ankara Üniversitesi Dil ve Tarih-Coğrafya Fakültesi Felsefe Bölümü Dergisi (Yayınlanmiyor).

Işıklı, Ş. (2010). Lotfi a. Zadeh'nin hayat hikâyesi ve bulanık paradigmanın üç temel unsuru. Kutadgubilig: Felsefe-Bilim Araştırmaları Dergisi, Sayı 17, ss.89-101

Ivan, C., Rumondor, P. C., Ricky, M. Y., Yossy, E. H., \& Budiharto, W. (2017). Help the math town: adaptive multiplayer math-science games using fuzzy logic. Procedia Computer Science, 116, 309-317.

Karac1, A. (2013). Ses sentezleme ve tanıma teknolojilerini kullanarak türkçenin ana dil olarak öğretimi İçin zeki öğretim sistemi geliştirilmesi. Gazi Üniversitesi, Bilişim Enstitüsü, Doktora Tezi

Karakış, E. (2018). Bulanik AHS ve bulanik moora yöntemleri ile okul öncesi eğitimi hizmet kalitesi değerlendirmesi ve anaokul seçimi. Cumhuriyet Üniversitesi İktisadi ve İdari Bilimler Dergisi 19(2): 184-98. 
Kazançoglu, Y., \& Aksoy, M. (2011). A fuzzy logic-based quality function deployment for selection of e-learning provider. Turkish Online Journal of Educational Technology-TOJET, 10(4), 39-45.

Kılıç, I., \& Moralar, A. (2015). Fen eğitiminde probleme dayalı öğrenme yaklaşımının akademik başarı ve motivasyona etkisi. Pegem Egitim ve Ogretim Dergisi, Pegem Journal of Education and Instruction, 5(5), 625.

Kuşçu, D. (2007). Karar verme süreçlerinde bulanık mantık yaklaşımı. Marmara Üniversitesi, Fen Bilimleri Enstitüsü, Elektronik ve Bilgisayar Eğitimi Anabilim Dalı, Yüsek Lisans Tezi.

Machado, M. A. S., Moreira, T. D. R. G., Gomes, L. F. A. M., Caldeira, A. M., \& Santos, D. J. (2016). A fuzzy logic application in virtual education. Procedia Computer Science, 91, 19-26.

Memmedova, K. (2017). Fuzzy logic modelling of the impact of using technology on anxiety and aggression levels of students. Procedia Computer Science, 120, 495-501.

Mert, Z. G., \& Yılmaz, S. (2009). Kocaeli mahalleleri donatı yeterliliğinin bulanık mantık yaklaşımı ile değerlendirilmesi. Eskişehir Osmangazi Üniversitesi Mühendislik ve Mimarlı Fakültesi Dergisi, 22(3), 167-183.

Namlı, N. A. (2016). Bulanık mantık ile belirlenmiş çoklu zeka alanlarına göre düzenlenmiş öğrenme ortamlarının öğrencilerin akademik başarılarına etkisi. Çukurova Üniversitesi, Bilgisayar ve Öğretim Teknolojileri Ana Bilim Dalı, Yüksek Lisans Tezi.

Ordukaya, E. (2011). Bulanık karar verme süreçlerinde geri bildirim ve mikro öğretim uygulaması. Marmara Üniversitesi, Fen Bilimleri Enstitüsü, Elektronik ve Bilgisayar Eğitimi Anabilim Dalı, Yüsek Lisans Tezi.

Öcal, A. (2015). Belirtisiz mantıktan yararlanılarak ortaöğretim matematik öğretmenliği öğrencilerinin öğretmenlik uygulaması başarılarının değerlendirilmesi. Hacettepe Üniversitesi, Eğitim Bilimleri Enstitüsü, Yüksek Lisans Tezi.

Özdemir, O. (2009). Bulanık mantık ile belirlenmiş öğrenme stillerine dayalı ögrrenme

ortamlarının ögrrencilerin başarı ve tutumlarına etkisi. Fırat Üniversitesi, Sosyal Bilimler Enstitüsü, Eğitim Bilimleri Bölümü, Eğitim Programları ve Öğretimi Anabilim Dalı, Doktora Tezi.

Ozdemir, O., \& Tekin, A. (2016). Evaluation of the presentation skills of the pre-service teachers via fuzzy logic. Computers in Human Behavior, 61, 288-299.

Papadimitriou, S., Chrysafiadi, K., \& Virvou, M. (2019). FuzzEG: fuzzy logic for adaptive scenarios in an educational adventure game. Multimedia Tools and Applications, 78(22), 32023-32053.

Rahemi, Jamileh. (2007). Self-Efficacy in english and iranian senior high school students majoring in humanities. Novitas-Royal 1(2).

Robles, D., \& Quintero M, C. G. (2020). Intelligent system for interactive teaching through videogames. Sustainability, 12(9), 3573.

Semerci, Ç. (2004). The influence of fuzzy logic theory on students' achievement. Turkish Online Journal of Educational Technology-TOJET, 3(2), 56-61.

Sgrò, F., Mango, P., Pignato, S., Piccolo, A. L., Nicolosi, S., Schembri, R., \& Lipoma, M. (2010). A neuro-fuzzy approach for student module of physical activity its. Procedia-Social and Behavioral Sciences, 9, 189-193.

$\mathrm{Su}$, C. H. (2017). A novel hybrid learning achievement prediction model: A case study in gamification education applications (APPs). International Journal of Information Technology \& Decision Making, 16(02), 515-543.

Sıramkaya, E. (2006). Veri madenciliğinde bulanık mantık uygulaması. Selçuk Üniversitesi, Fen Bilimleri Enstitüsü, Yüksek Lisans Tezi.

Sugeno, M., Asai, K., \& Terano, T. (1992). Fuzzy systems theory and its applications. Tokyo Institute of Technology.

Şen, Z. (2001). Bulanık mantık ve modelleme ilkeleri. İstanbul, Türkiye: Bilge Kültür Sanat.

Şengül, Ü., E. Miraç., \& Shiraz, S. E. (2012). Bulanik AHP ile belediyelerin toplu taşıma araç seçimi. Erciyes Üniversitesi İktisadi ve İdari Bilimler Fakültesi Dergisi, (40), 143-165.

Şirin, S. R. (2005). Socioeconomic status and academic achievement: A meta-analytic review of research. Review of educational research, 75(3), 417-453.

Taşkın, H., Üstün, Ö., \& Deliktaş, D. (2013) Fuzzy mcdm approach for oral examınatıon ın erasmus student selection process. Dumlupınar Üniversitesi Fen Bilimleri Enstitüsü Dergisi, (032), 21-40.

Turan, S., \& Demirel, Ö. (2010). Öz-düzenleyici öğrenme becerilerinin akademik başarı ile ilişkisi: Hacettepe üniversitesi tıp fakültesi örneği. Hacettepe Üniversitesi Eğitim Fakültesi Dergisi, 38(38), 279-291.

Troussas, C., Krouska, A., \& Sgouropoulou, C. (2020). Collaboration and fuzzy-modeled personalization for mobile game-based learning in higher education. Computers \& Education, 144, 103698.

Uysal, H. (2015). BÖTE öğrencilerinin akademik başarllarını etkileyen faktörlerin belirlenmesi ve akademik başarı tahmin modelinin geliştirilmesi. Çanakkale 18 Mart Üniversitesi, Bilgisayar ve Öğretim Teknolojileri Eğitimi Ana Bilim Dalı, Yüksek Lisans Tezi.

Uysal, M. (2016). Bulanık mantık tabanlı dunn öğrenme stili modeli gerçekleştirimi. Manisa Celal Bayar Üniversitesi, Fen Bilimleri Enstitüsü, Yüksek Lisans Tezi.

Uysal, M., Mülayim, N., Özdemir, A., \& Alaybeyoğlu, A. (2014-Şubat). Bulanık mantık tabanlı dunn öğrenme stili modelinin geliştirimi. 16. Akademik Bilişim Konferansı içinde (642-643. ss), Adnan Menderes Üniversitesi, Aydın, Türkiye.

Uzun, K. P. 2008. Mesleki ve teknik eğitim okullarında öğrencileri alana yöneltmede uzman sistem yaklaşımı. Marmara Üniversitesi, Fen Bilimleri Enstitüsü, Elektronik-Bilgisayar Eğitimi Anabilim Dalı, Yüksek Lisans Tezi.

Zadeh, L. A. (1965). Information and control. Fuzzy sets, 8(3), 338-353.

Zimmerman, B. J. (1990). Self-regulated learning and academic achievement: An overview. Educational psychologist, 25(1), 3-17. 